\title{
The Anticandidal and Toxicity Properties of Lampranthus francisci
}

\author{
Batanai Moyo and Stanley Mukanganyama \\ Department of Biochemistry, University of Zimbabwe, Mt. Pleasant, Harare, Zimbabwe \\ Correspondence should be addressed to Stanley Mukanganyama; smukanganyama@medic.uz.ac.zw
}

Received 17 July 2015; Revised 17 September 2015; Accepted 20 September 2015

Academic Editor: Samuel A. Lee

Copyright (C) 2015 B. Moyo and S. Mukanganyama. This is an open access article distributed under the Creative Commons Attribution License, which permits unrestricted use, distribution, and reproduction in any medium, provided the original work is properly cited.

\begin{abstract}
Fungal infections have been rising due to the increasing number of immunocompromised patients and intensive use of some antifungal agents. Lampranthus francisci is an ornamental succulent plant. In Zimbabwe, the fresh sap from the leaves is used to treat fungal scalp infections. The activity of $L$. francisci fresh and dry acetone, ethanol, hydroethanolic, and aqueous extracts against Candida albicans and Candida krusei was determined. Mouse peritoneal cavity cells and sheep red blood cells were used to investigate $L$. francisci's toxicity profile. The hydroethanolic extracts were the most effective extracts against $C$. albicans. The fresh ethanol extract was the most effective extract against $C$. krusei. The dry acetone extract, dry ethanol extract, and the fresh and dry aqueous extracts promoted the growth of C. krusei. The hydroethanolic extracts caused haemolysis of sheep cells. The hydroethanolic extracts promoted the growth of the mouse peritoneal cavity red blood cells. Both aqueous extracts increased the density of the mouse cells, but only the fresh extract increased the metabolism of the mouse cells. L. francisci has some fungicidal activity and boosts the growth of immune cells, thus validating its use in ethnomedicine. L. francisci extracts are potential leads for the isolation of immune stimulatory compounds.
\end{abstract}

\section{Introduction}

Candidiasis refers to the systemic and superficial infections that are caused by yeasts that belong to the genus Candida [1]. Two hundred species such as Candida kefyr, Candida parapsilosis, Candida guilliermondii, Candida tropicalis, and Candida glabrata belong to the genus Candida [2,3]. Candida is the 4th leading cause of nosocomial infections but is responsible for the most deaths due to nosocomial infections, surpassing those caused by S. aureus [4]. In the United States, a $320 \%$ increase in the number of deaths caused by invasive fungal infections was noted between 1980 and 1997 [5]. C. albicans, C. glabrata, C. tropicalis, and C. parapsilosis are Candida species that are normally implicated in invasive fungal infections [6].

Up to $80 \%$ of healthy adults have Candida in their gastrointestinal tracts, while up to $60 \%$ have the yeasts in their saliva [7]. However, due to the rise in the number of immunocompromised patients due to HIV/AIDs and organ transplantation, the increased use of drugs that modulate the immune system in the treatment of diseases such as rheumatoid arthritis and cancer, and the use of implanted medical devices, candidiasis has emerged as an opportunistic infection $[1,8]$. Ten percent of all opportunistic infections are caused by Candida [7].

In this study, C. albicans and C. krusei were used to test the antifungal activity of $L$. francisci. C. albicans was selected as it is responsible for most Candida infections, while C. krusei was selected as it is a clinical strain $[9,10]$. C. albicans can exist as yeast, pseudohyphal, or hyphal forms [11] and normally colonises humans and other mammals $[4,12]$. The Candida albicans cell wall comprises chitin and $\beta$ glucans and is covered by mannoproteins [13]. The functions of the mannoproteins include adhesion, obtaining nutrients for the fungi, the formation of biofilms and the breakdown of tissue [13]. C. albicans is able to transform from a harmless, commensal pathogen into a deadly invasive pathogen under the influence of the external environmental factors [4]. 
Candida krusei can cause serious infections in the immunocompromised patients [10]. C. krusei is a facultative saprophyte [14]. C. krusei infections are normally seen in bone marrow and blood transplant patients, as well as those suffering from hematologic malignancies [15]. C. krusei infections were discovered in hospitals before fluconazole was used for antifungal treatment [16], showing that infection by C. krusei is not necessarily encouraged by the use of fluconazole. $C$. krusei causes pneumonia and onycholysis [17]. Mortality rates of 30-60\% are associated with C. krusei infection [18]. C. kru$s e i$ is intrinsically resistant to fluconazole and shows reduced sensitivity to amphotericin B and flucytosine [15]. Resistance to fluconazole in C. krusei is due to reduced sensitivity to azoles by the cytochrome P450 14 $\alpha$-demethylase YP51 [10].

Drugs used to treat candidiasis include itraconazole, caspofungin, voriconazole, and amphotericin B [19]. The intensified use of fluconazole in antifungal treatment has led to a change in the population of Candida species and thus the development of azole resistance [1]. Azole resistance in C. albicans has been noted in HIV-infected individuals who suffer from recurrent oropharyngeal candidiasis as well as in critically ill adults with invasive candidiasis [19]. Resistance to fluconazole by C. albicans was noted as early as the $1990 \mathrm{~s}$ [20]. In the immunocompromised patients, candidiasis may lead to death [9]. New antifungal drugs are needed to replace those that can no longer be used due to resistance.

Plants have been used for millennia to treat many diseases [9]. Plant extracts contain a large variety of compounds with diverse chemical classes, increasing their activity profile against pathogens [21]. Medicinal compounds found in plant extracts include antibacterial, antifungal, antioxidant, and antitumour compounds, as well as compounds that treat diabetes, infertility, and the nervous system [9]. Plants synthesise many active compounds, known as secondary metabolites, which may be either free or combined with other compounds that may or may not be medicinally active [22]. Many pharmaceutical agents have either come directly from plants or have been derived from plant constituents. Examples include paclitaxel, camptothecin, artemicin, silymarin, galantamine, colchicine, d-tubocurarine, and tiotropium [23, 24]. Half of the pharmaceutical agents in use are plant compounds, derived from plant compounds or analogues of plant compounds [23]. The versatility of plant compounds has led to their use in nutraceuticals and supplements and as the basis for synthetic drugs [25].

Some plants have the ability to stimulate the immune system. Stimulation of the immune system to fight infections is particularly important in patients with weakened immune systems. Allium sativum and Plantago major have been found to stimulate the immune system [26]. Hemidesmus indicus stimulated the proliferation of lymphocytes [26]. Rhaphidophora korthalsii has been found to encourage the growth of human peripheral blood mononuclear cells in vitro [27], while Grifola frondosa has also been found to stimulate an immune response [28].

Generally, plants are considered to be safe as many of them are used for food; they are easily available, exhibit low toxicity, and have fewer side effects than conventional medicines [29]. Research is needed to ensure that these plants are not in fact harmful to human health. Toxic constituents, pesticides, heavy metals such as lead and arsenic, and microorganisms may cause a plant extract to be dangerous $[30,31]$.

Lampranthus francisci is a succulent plant, mostly found in southern Africa, which flowers between June and August. L. francisci belongs to the order Caryophyllales and the family Aizoaceae [32]. Aizoaceae contains 257 genera and 5345 species [33]. The genus Lampranthus is also known as Mesembryanthemum [34]. Plants from the genus have been used as food, for example, $M$. forsskaolii may be used instead of wheat flour [35]. Essential oils from Lampranthus multiradiatus (Mesembryanthemum edule) leaves have been used by traditional healers in South Africa for the treatment of respiratory tract infections, tuberculosis, dysentery, diabetic mellitus, laryngitis, and vaginal infections [36]. Several studies have shown that plants from this genus have antifungal, antiyeast, and antibacterial activity [36-38]. It has also been reported that other Lampranthus species such as Lampranthus sociorum are sources of pigments that have been shown to have activity against oral microbial organisms such as Streptococcus and Candida [39].

Traditionally, L. francisci is used in Zimbabwe to treat fungal infections of the scalp, commonly known as zvisasa (Mukanganyama, personal communication). The fresh sap from a fresh leaf is squeezed onto the scalp and the infection disappears. L. francisci is used to prevent soil erosion and as an ornamental plant due to the pleasant appearance of its colourful flowers [40]. L. francisci absorbs nutrients and water in soil for storage in its succulent leaves [40].

With the rapid increase in drug resistant infections and the escalating cost of healthcare all over the world, the investigation of new sources of antifungal compounds is important. New antifungal compounds with novel mechanisms of action are needed to treat drug resistant pathogens. The constantly rising costs of healthcare are exacerbated by the increased drug costs due to an increase in drug development costs. The main objective of this project was to investigate the antifungal activities of $L$. francisci extracts against $C$. albicans and $C$. $k r u s e i$ in order to validate the claimed antimicrobial activities by local populations in Zimbabwe.

\section{Materials and Methods}

2.1. Chemicals and Reagents. The chemicals, reagents, and media used in this study were purchased from SigmaAldrich (Steinheim, Germany). The chemicals and media used were dimethyl sulfoxide (DMSO), acetone, ethanol, 3(4,5-dimethylthiazol-2-yl)-2,5-diphenyltetrazolium bromide (MTT), 2-(4-iodophenyl)-3-(4-nitrophenyl)-5-phenyl-2Htetrazolium (INT), Sabouraud dextrose broth (SDB), Sabouraud dextrose agar (SDA), nutrient broth number 1 , nutrient agar, Roswell Park Memorial Institute media 1640 without phenol red (RPMI $1640 \mathrm{PR}^{-}$), rhodamine 6G (R6G), Hanks Buffered Salt Solution (HBSS), trypan blue dye, miconazole, sodium citrate, dextrose, citric acid, sodium chloride, and starch. 
2.2. Plant Collection and Preparation of Plant Extracts. L. francisci leaves were collected from the University of Zimbabwe main campus (GPS coordinates: $17.7840^{\circ} \mathrm{S}, 31.0530^{\circ} \mathrm{E}$ ), Mount Pleasant, Harare, Zimbabwe. The plant was identified by a botanist, Mr. Christopher Chapano, of the National Botanical and Herbarium Garden (Harare, Zimbabwe). Fresh and dry extracts of the leaves were prepared using different solvents, namely acetone, ethanol, $70 \%$ ethanol in water, and water. The leaves collected were separated into 2 , with $1 / 3$ of the leaves being used to prepare the fresh leaf extracts, and the remaining $2 / 3$ being dried to prepare the dry leaf extracts. The fresh leaves were macerated using a pestle and mortar; then the sap was filtered using Whatman number 1 filter paper. This aqueous extract was dried under a stream of moving air until being dry. Five hundred millilitres of acetone, $70 \%$ ethanol in water, and ethanol were added to the fresh plant material that remained to prepare the acetone, hydroethanolic, and ethanol extracts, respectively.

The remaining two-thirds of plant material were dried in an oven at $40^{\circ} \mathrm{C}$ until dry for 10 days (Lab Design Engineering (Pty) Ltd., Maraisburg, South Africa). The dried leaves were ground to a fine powder in a blender (Philips Co., Shanghai, China). To fifty grams of the dry leaf powder, $500 \mathrm{~mL}$ of solvent was added. The solvents used were acetone, ethanol, $70 \%$ ethanol in water, and water.

For both the fresh and dry extracts, the extractions were allowed to proceed for 20 hours. The extracts were filtered using Whatman number 1 filter paper. The acetone and ethanol extracts were dried using a Rotoevaporator (Rotavapour RII, BUCHI, Flawil, Switzerland). The hydroethanolic and water extracts were dried under a stream of moving air. The extracts were collected, weighed, and stored in the dark at room temperature. When used in the assays, the extracts were filter-sterilised using a Millex-GV $0.22 \mu \mathrm{M}$ filter (Millipore, Molsheim, France).

2.3. Growth of Candida albicans and Candida krusei. C. albicans ATCC 10231 and a clinical strain of C. krusei isolated from a patient with candidiasis at Parirenyatwa Hospital (Harare, Zimbabwe) that was provided by Dr. V. Robertson (Department of Medical Microbiology, University of Zimbabwe) were used in this study. C. albicans and C. krusei were resuscitated from glycerol stocks stored at $-33^{\circ} \mathrm{C}$. C. albicans was grown in $\mathrm{SDB}$ overnight at $37^{\circ} \mathrm{C}, 120$ revolutions per minute (rpm) (Lab Companion, Jeio Tech, Seoul, South Korea). C. krusei was grown in nutrient broth under the same conditions as C. albicans. C. albicans and C. krusei were streaked onto SDA and nutrient agar plates, respectively, using a sterile inoculating loop. The plates were placed in an incubator and the fungi were allowed to grow overnight at $37^{\circ} \mathrm{C}$. The plates were stored at $4^{\circ} \mathrm{C}$, and when required for an assay, a colony was inoculated into fresh, sterile liquid media for growth for $18 \mathrm{~h}$. The effect of different concentrations of DMSO on the growth of C. albicans and C. krusei was determined since the different solvent extracts were dissolved in DMSO before they were diluted to the appropriate concentrations using either SDB or nutrient broth.
2.4. Screening L. francisci for Antifungal Activity. One C. albicans colony was inoculated into sterile SDB and grown at $37^{\circ} \mathrm{C}, 120 \mathrm{rpm}$ overnight. McFarland's Standard (0.5) was prepared. The C. albicans culture was standardised by determining the absorbance at $600 \mathrm{~nm}$ in UNICO 280 UV spectrophotometer and a stock solution of $2 \times 10^{6} \mathrm{cfu} / \mathrm{mL}$ was prepared. $L$. francisci acetone, ethanol, and hydroethanolic extracts were first dissolved in DMSO and then diluted to the appropriate concentration using media. The aqueous extract was initially dissolved in sterile distilled water. The extracts were used at concentrations of $0 \mathrm{mg} / \mathrm{mL}, 0.05 \mathrm{mg} / \mathrm{mL}, 0.1 \mathrm{mg} / \mathrm{mL}$, $0.25 \mathrm{mg} / \mathrm{mL}, 0.5 \mathrm{mg} / \mathrm{mL}$, and $1 \mathrm{mg} / \mathrm{mL}$. The miconazole was used at concentrations of $0 \mu \mathrm{g} / \mathrm{mL}, 6.25 \mu \mathrm{g} / \mathrm{mL}, 12.5 \mu \mathrm{g} / \mathrm{mL}$, $25 \mu \mathrm{g} / \mathrm{mL}, 50 \mu \mathrm{g} / \mathrm{mL}$, and $100 \mu \mathrm{g} / \mathrm{mL}$.

The C. albicans, L. francisci extracts, and miconazole were grown on 96-well microplates. The final concentration of cells was $1 \times 10^{6} \mathrm{cfu} / \mathrm{mL}$, and the final DMSO concentration was $3 \%$. The absorbance readings of the plates were determined using a Genios Pro microplate reader (Tecan Instruments, Grodig, Austria) at $590 \mathrm{~nm}$. Plates were then incubated for 18 hours at $37^{\circ} \mathrm{C}$ in a humidified incubator. The absorbance was measured again at $590 \mathrm{~nm}$, before adding $25 \mu \mathrm{L}$ of INT to each well. The plates were incubated for further 2 hours before the absorbance was read for a third and final time at $590 \mathrm{~nm}$. The same procedure for the screening assay was repeated with $C$. krusei, but nutrient broth was used instead of SDB as C. krusei grew better in nutrient broth.

2.5. Determination of the Effects of L. francisci on the Haemolysis of Sheep Red Blood Cells. The haemolysis assay was used to determine the toxicity effects of $L$. francisci fresh and dry hydroethanolic extracts on sheep red blood cells. The assay was based on a method described by Orsine et al. [41] with modifications. Cellular plasma membrane permeabilization by various factors are usually studied by employing the use of red blood cells and in this red blood from adult sheep was used. Fifty millilitres of blood was added to a flask containing $1 \mathrm{mM} \mathrm{Na-citrate.} \mathrm{The} \mathrm{blood} \mathrm{was} \mathrm{mixed}$ with an equal volume of Alsever solution containing 2.05\% dextrose, $0.8 \%$ sodium citrate, $0.055 \%$ citric acid, and $0.42 \%$ sodium chloride. Twenty millilitres of blood was centrifuged at $3000 \mathrm{rpm}$ for 10 minutes. The supernatant was discarded. The cells were washed in phosphate buffered saline (PBS) five times their volume three times. Two hundred microliters of cells were incubated with an equal volume of $L$. francisci extracts for 1 hour in a water bath at $37^{\circ} \mathrm{C}$ (Rotavapour RII, BUCHI, Flawil, Switzerland). L. francisci was used at concentrations of $0.25 \mathrm{mg} / \mathrm{mL}, 1 \mathrm{mg} / \mathrm{mL}$, and $5 \mathrm{mg} / \mathrm{mL}$. The samples were centrifuged in a microcentrifuge for $1 \mathrm{~min}$ (Hermle Z233M-2, Hermle Labortechnik, Wehingen, Germany). Two hundred microliters was added to $3 \mathrm{~mL}$ Drabkin's reagent $(200 \mathrm{mg}$ potassium ferricyanide, $50 \mathrm{mg}$ potassium cyanide, $140 \mathrm{mg}$ potassium dihydrogen phosphate, and $1 \mathrm{~mL}$ nonionic detergent, in $1 \mathrm{~L}$ of distilled water). The absorbance of the haemoglobin released was measured at $590 \mathrm{~nm}$ using an ELISA reader. The positive control was prepared by adding $200 \mu \mathrm{L}$ of uncentrifuged erythrocyte suspension to $200 \mu \mathrm{L}$ of buffer, then adding to $3 \mathrm{~mL}$ Drabkin's reagent. The 
positive control was treated as $100 \%$ haemolysis. The negative control was prepared by mixing $200 \mu \mathrm{L}$ PBS with $200 \mu \mathrm{L}$ erythrocytes, centrifuging for 1 minute, then adding $200 \mu \mathrm{L}$ to $3 \mathrm{~mL}$ Drabkin's reagent. The percentage haemolysis was determined by dividing the absorbance of each sample by that of the positive control, then multiplying by 100 .

2.6. Effect of L. francisci on Mouse Peritoneal Cavity Cells. The effects of $L$. francisci on mouse peritoneal cavity cells was conducted according to the methods described by Ray and Dittel [42] and Saha et al. [43]. The peritoneum is a cavity in the abdomen, filled with fluid and containing a variety of cells that include macrophages, B-cells, and T-cells, which are immune cells [42]. The assay would, therefore, allow investigation into the toxicity of $L$. francisci and its activities on the immune system and the extracts that showed potency; the hydroethanolic and aqueous were used.

Five male Balb/c mice aged approximately 8 weeks and weighing, on average $24.8 \mathrm{~g}$, were collected from the University of Zimbabwe, Animal House (Mount Pleasant, Harare, Zimbabwe). The study was approved by the University of Zimbabwe, Department of Biochemistry Research Ethics Committee (01. 11. 11, UZBREC ref: 04/14). The mice were fed with certified food pellets rodent comroids (National foods (PVT), Ltd., Harare Zimbabwe) ad libitum and allowed free access to tap water. The mice were injected intraperitoneally with $1 \mathrm{~mL} 20 \% \mathrm{w} / \mathrm{v}$ starch solution. The starch solution was used to stimulate an immune response as starch is a "foreign object," resulting in a high yield of immune cells. The animals were left for 24 hours with free access to food (pelleted mouse feed) and drinking water. The following day, the animals were sacrificed by cervical dislocation. Cervical dislocation prevents blood from contaminating the peritoneal cavity [42]. The mice were sprayed using $70 \%$ ethanol, then mounted onto a styrofoam board, and secured at the paws. The outer skin of the peritoneum was cut to expose the inner skin of the peritoneum. Five millilitres of ice cold Hanks Buffered Salt Solution (HBSS) containing 3\% foetal calf serum (FCS) was injected into the peritoneal cavity. The peritoneum was gently massaged to dislodge cells from the wall of the peritoneal cavity. As much liquid as possible was collected using a needle and syringe. The inner skin was then cut to expose the inside of the peritoneal cavity; then a Pasteur pipette was used to collect any remaining liquid. The cells collected were placed in a collection tube that was kept on ice at all times.

The cells were centrifuged at $1500 \mathrm{rpm}$ for 10 minutes (Hettich Rotofix 32 Centrifuge, Tuttlingen, Germany). The supernatant was discarded, and the cells were resuspended in ice-cold Rosewel Park Memorial Institute 1640 media without phenol red indicator (RPMI $1640 \mathrm{PR}^{-}$). To a small flask, $10 \mathrm{~mL}$ of cells was added, while to a large flask, $15 \mathrm{~mL}$ of cells was added, before RPMI $1640 \mathrm{PR}^{-}$was added to make a final volume of $50 \mathrm{~mL}$. The cells were grown overnight in culture flasks at $37^{\circ} \mathrm{C}$ with $5 \% \mathrm{CO}_{2}$ (Shellab $\mathrm{CO}_{2}$ Series, Sheldon Mfg. Inc., Cornelius, USA).

2.7. Determination of the Effect of L. francisci Extracts on the Growth and Metabolic Activity of Mouse Peritoneal Cavity Cells. Two assays were conducted to determine the effect of L. francisci hydroethanolic and aqueous extracts on the growth of mouse peritoneal cavity cells. The assays were the trypan blue exclusion assay, which measures the number of live and dead cells by counting, and the MTT assay, which measures the metabolic activity of the cells. Trypan blue is added to cells and only stains the dead cells, allowing differentiation between the two when looking under the microscope. The MTT assay measures the metabolic activity of the cells by measuring the reduction of yellow MTT to purple formazan crystals by live cells [44].

2.8. Statistical Analyses. To analyse the data obtained in this study, one-way analysis of variance test (ANOVA) with Dunnett's Multiple Comparison Test was used. A $P$ value of 0.05 or less was considered statistically significant. The software used was GraphPad Prism 5 for Windows (GraphPad Software Inc., San Diego, California, USA) version 5.03.

\section{Results}

3.1. The Effect of DMSO on the Growth of C. albicans and C. krusei. The acetone, hydroethanolic, and ethanol fresh and dry extracts were dissolved in DMSO as they were incapable of dissolving in any other solvent. An assay to determine the effect of various concentrations of DMSO on the growth of C. albicans and C. krusei was, thus, necessary. The results are shown in Figure 1. Growth of the treated cells was compared to the growth of the untreated cells (0\% DMSO). Significant reductions in the growth $C$. albicans were seen at $1 \%$ and $5 \%$ DMSO. At 5\% DMSO, the percentage growth of C. albicans was $79.4 \%$ of the untreated cells, corresponding to a $20.6 \%$ decrease in growth.

At all tested concentrations, the growth of C. krusei was significantly higher than the untreated control. As the concentration of DMSO increased, the increase in growth compared to the untreated control decreased as at $1 \%$ DMSO, and the growth of C. krusei was $189 \%$ of the untreated cells, while, at $5 \%$ DMSO, the growth was $132 \%$ of the untreated cells.

3.2. Screening L. francisci for Antifungal Activity. L. francisci extracts were tested against C. albicans and C. krusei to determine their antifungal activity. Miconazole was used as the positive control and media alone as the negative control.

3.2.1. The Effects of Miconazole on the Growth of Candida. The effects of miconazole on the growth of Candida are shown in Figure 2. Against C. albicans, the final concentration of DMSO used was 3\% in each well as it was shown that it had no effect on the growth of $C$. albicans. As the concentration of miconazole increased, the growth of $C$. albicans decreased in a dose-dependent manner.

DMSO alone encouraged the growth of C. krusei at 3\% DMSO. The miconazole overcame the growth stimulatory effect of DMSO and inhibited the growth of C. krusei at all tested concentrations.

3.2.2. The Effects of the Acetone Extract. The effects of $L$. francisci acetone extracts on the growth of Candida are shown 
C. albicans

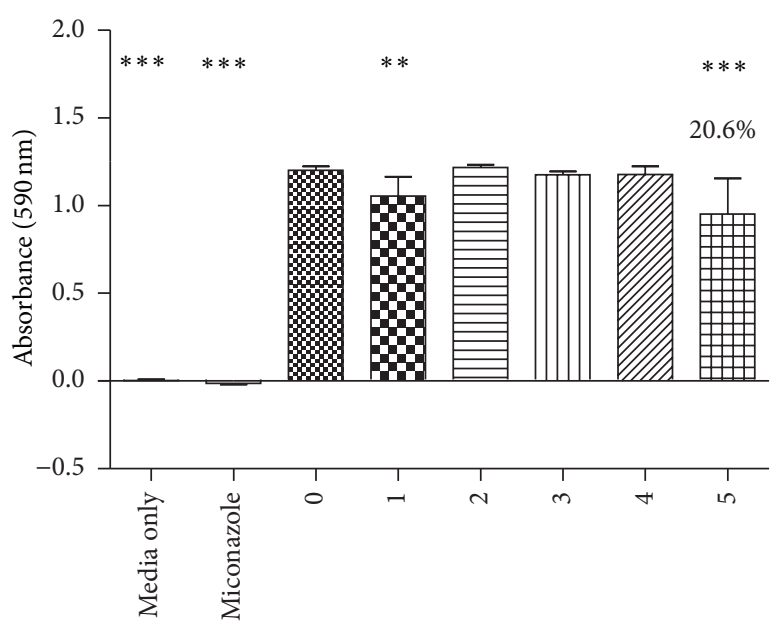

$\operatorname{DMSO}(\%)$
C. krusei

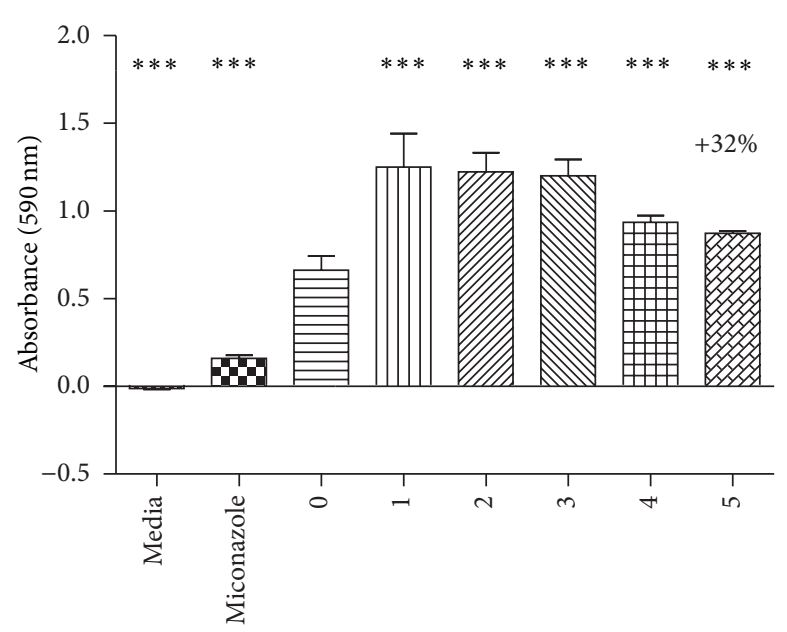

DMSO (\%)

FIGURE 1: The effect of DMSO on the growth of Candida albicans and Candida krusei. Miconazole was used at a concentration of $50 \mu \mathrm{g} / \mathrm{mL}$ as a positive control, while media only were used as the negative control. The percentage growth inhibition at $5 \%$ DMSO is shown on the graph. At all tested concentrations of DMSO, the extract encouraged growth of the C. krusei cells. Growth of cells was compared to the growth at $0 \%$ DMSO. ${ }^{* *} P<0.001 ;{ }^{* * *} P<0.0001 . N=12$.
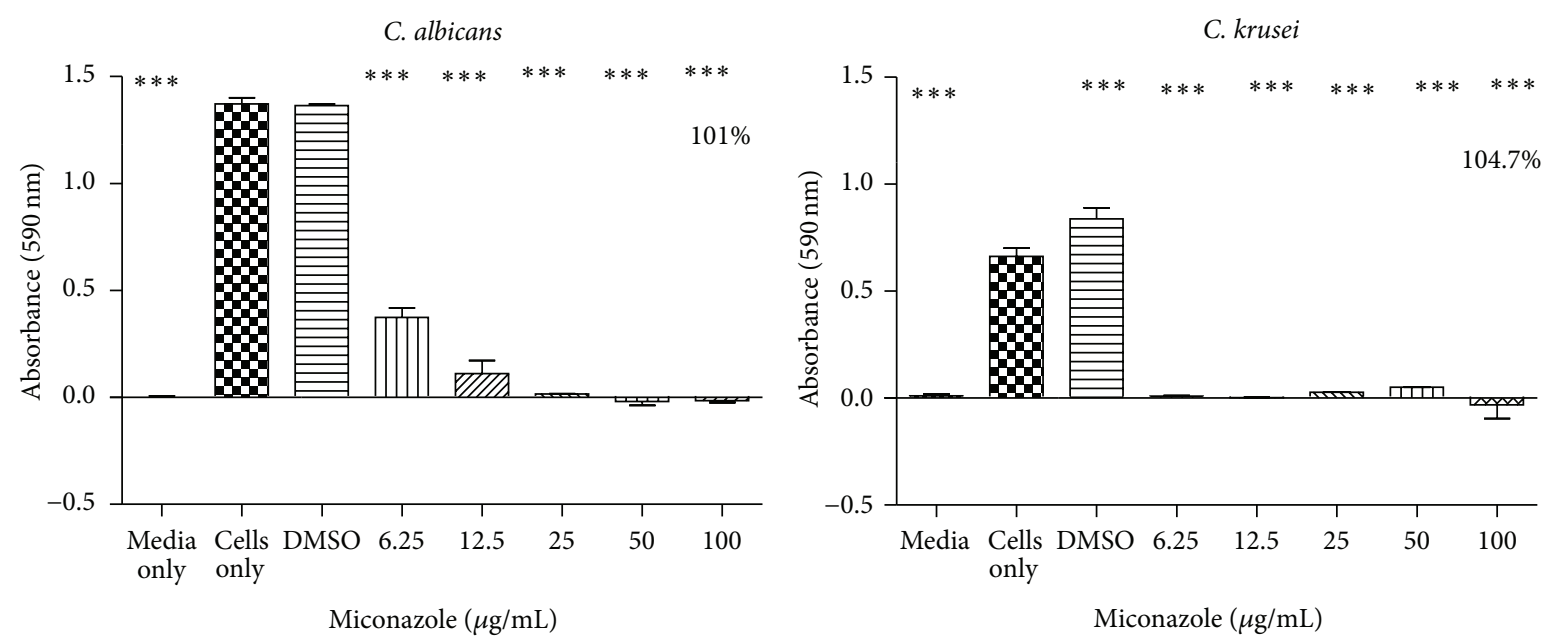

Figure 2: The effect of miconazole on the growth of Candida albicans and Candida krusei. DMSO was used at a final concentration of $3 \%$. Growth of C. albicans and C. krusei after treatment with miconazole was compared to the growth of the untreated cells. Growth of $C$. albicans decreased as the concentration of miconazole increased. At the highest concentration of miconazole used, $100 \mu \mathrm{g} / \mathrm{mL}$, the growth of C. albicans was reduced by $101 \%$. At the highest tested concentration, $100 \mu \mathrm{g} / \mathrm{mL}$, miconazole was able to reduce the growth of C. $\mathrm{krusei}$ by 104.7\%. Growth inhibition was significant at all tested concentrations. ${ }^{* * *} P<0.0001 . N=2$.

in Figure 3. At $1 \mathrm{mg} / \mathrm{mL}$ of the fresh acetone extract, the growth of C. albicans was reduced by $28 \%$. The dry extract had no effect on the growth of C. albicans at all tested concentrations.

The fresh acetone extract reduced the growth of C. krusei at all tested concentrations despite the stimulatory activity of DMSO. An increase in growth was seen from $0.5 \mathrm{mg} / \mathrm{mL}$ to $1 \mathrm{mg} / \mathrm{mL}$, but the growth at $1 \mathrm{mg} / \mathrm{mL}$ was still lower than the growth seen in the untreated cells. The dry acetone extract encouraged the growth of C. krusei to a greater extent than DMSO. The dry extract caused an increase in the growth of
C. krusei in a dose-dependent manner. At $0.5 \mathrm{mg} / \mathrm{mL}$ and $1 \mathrm{mg} / \mathrm{mL}$ of the dry acetone extract, the growth of C. krusei was $205.1 \%$ and $200 \%$ of the untreated cells, respectively.

3.2.3. The Effects of $L$. francisci Fresh and Dry Ethanol Extracts. The activities of the $L$. francisci fresh and dry ethanol extracts against C. albicans are shown in Figure 4. The fresh extract reduced the growth of C. albicans in a concentration-dependent manner. The dry extract was effective against C. albicans at $0.25 \mathrm{mg} / \mathrm{mL}, 0.5 \mathrm{mg} / \mathrm{mL}$, and $1 \mathrm{mg} / \mathrm{mL}$ only, with growth inhibitions of $10 \%, 51 \%$, and 


\section{C. albicans}

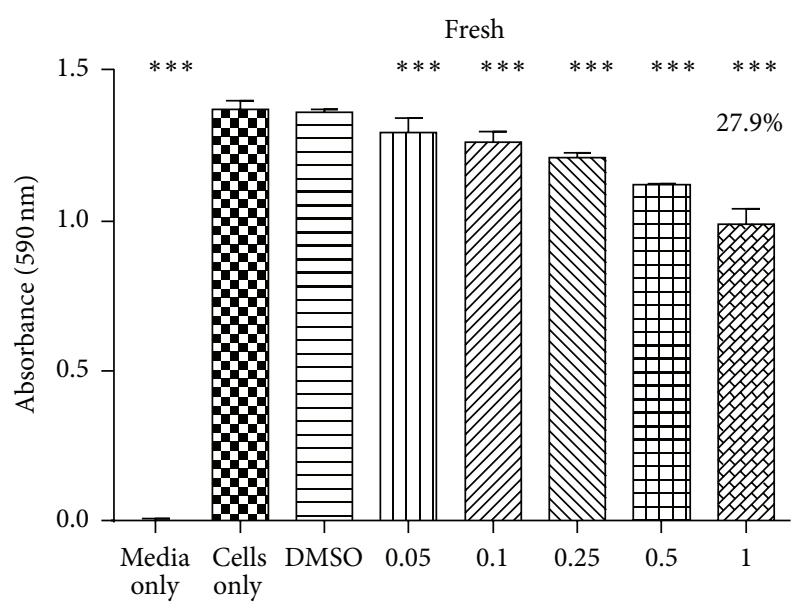

Concentration of $L$. francisci $(\mathrm{mg} / \mathrm{mL})$

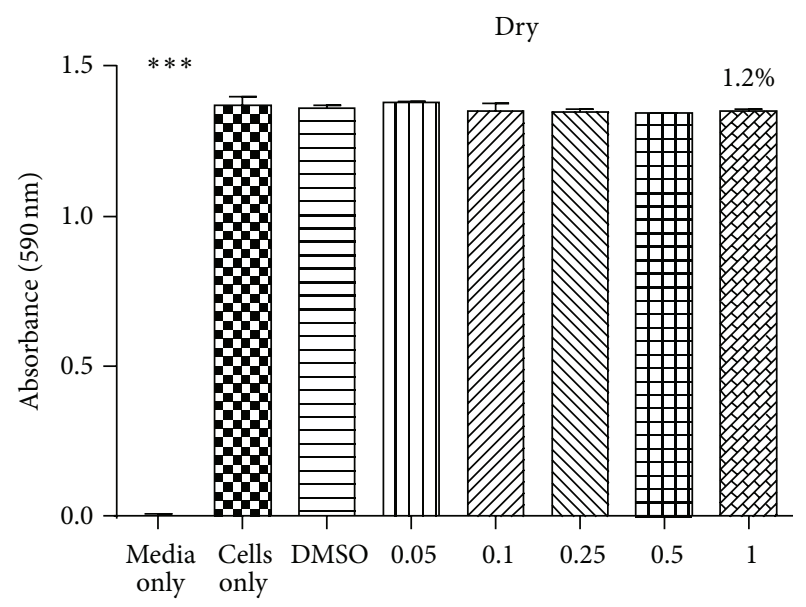

Concentration of L. francisci $(\mathrm{mg} / \mathrm{mL})$

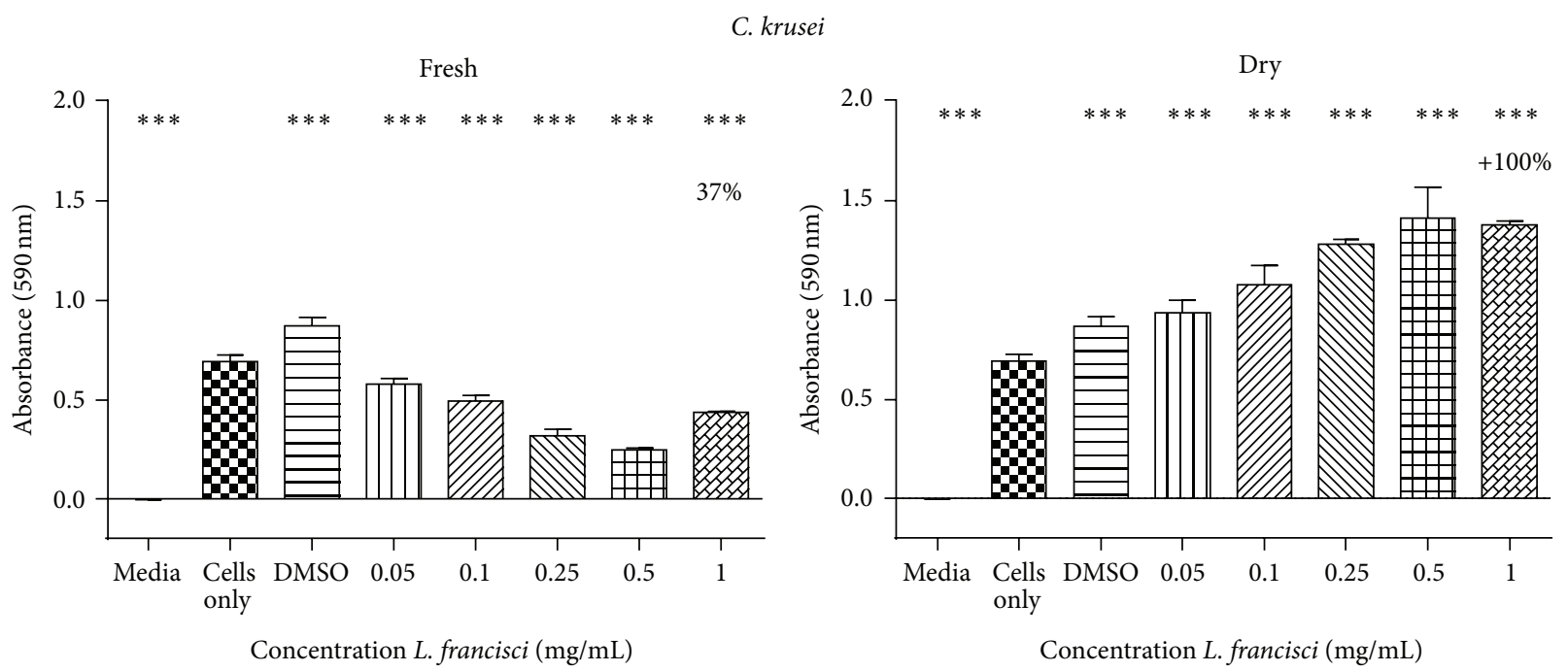

Figure 3: The effects of the fresh and dry L. francisci acetone extracts on the growth of Candida albicans and Candida krusei. Growth of C. albicans and C. krusei at the tested concentrations was compared to the growth of the untreated cells. The fresh extract was more effective against $C$. albicans than the dry extract. The fresh extract reduced the growth of $C$. krusei while the dry extract encouraged the growth of $C$. krusei. At $1 \mathrm{mg} / \mathrm{mL}$, the fresh extract reduced the growth of C. krusei by $37 \%$, while the dry extract increased growth of C. krusei by $100 \%$. ${ }^{* * *} P<0.0001 . N=4$.

$76 \%$, respectively, compared to the untreated control. At $0.5 \mathrm{mg} / \mathrm{mL}$ and $1 \mathrm{mg} / \mathrm{mL}$, the dry extract was more effective as a growth inhibitor than the fresh extract at the same concentrations.

The fresh ethanol extract decreased the growth of $C$. krusei at all tested concentrations compared to the untreated control despite the growth stimulatory activity of DMSO. The growth of C. krusei was decreased to less than $50 \%$ compared to $0 \mathrm{mg} / \mathrm{mL}$ at $0.25 \mathrm{mg} / \mathrm{mL}, 0.5 \mathrm{mg} / \mathrm{mL}$, and $1 \mathrm{mg} / \mathrm{mL}$ of the fresh ethanol extract. The dry ethanol extract encouraged the growth of C. krusei in a dose-dependent manner. At $0.05 \mathrm{mg} / \mathrm{mL}$ of the dry extract, the growth of C. krusei was increased by $36 \%$. At $1 \mathrm{mg} / \mathrm{mL}$, the growth had increased by $64.1 \%$.
3.2.4. The Effects of the Fresh and Dry Hydroethanolic Extracts. The effects of the fresh and dry hydroethanolic extracts on the growth of Candida are shown in Figure 5. Both extracts reduced the growth of $C$. albicans at all tested concentrations in a dose-dependent manner. The fresh extract was more effective than the dry extract at lower concentrations.

The growth of the C. krusei cells treated with the fresh extract was generally similar to the growth of the untreated C. krusei cells. The DMSO encouraged the growth of $C$. krusei by $20 \%$, so the extract cancelled any stimulatory effect of the DMSO on C. krusei. The dry extract reduced the growth of C. krusei at $0.5 \mathrm{mg} / \mathrm{mL}$ and $1 \mathrm{mg} / \mathrm{mL}$ by $35.2 \%$ and $26.8 \%$, respectively. The growth at the remaining tested concentrations was similar to the untreated cells. 


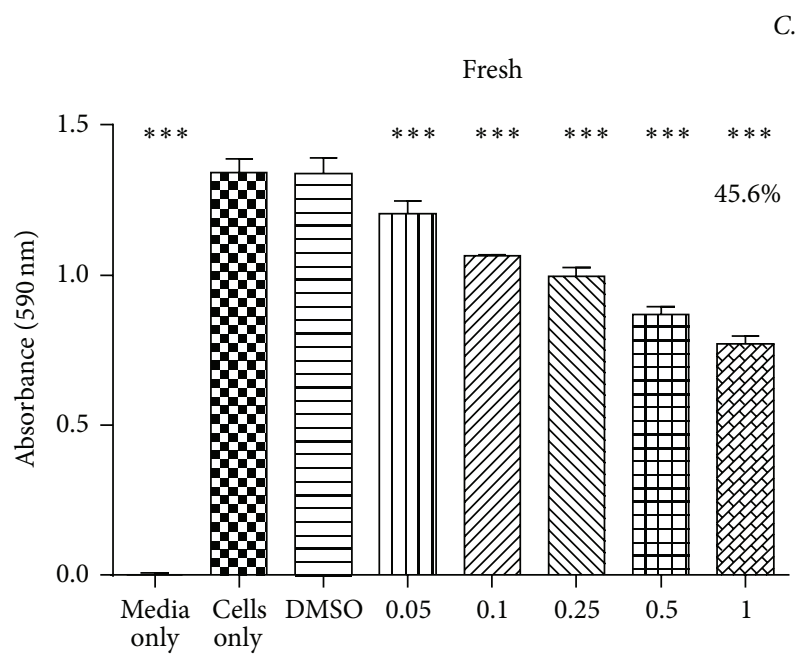

Concentration of $L$. francisci $(\mathrm{mg} / \mathrm{mL})$

\section{C. albicans}

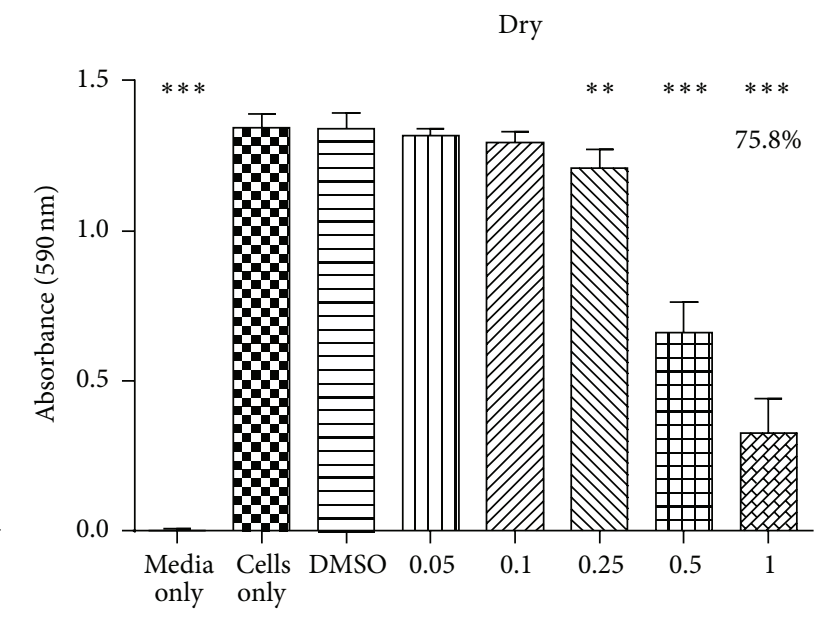

Concentration of $L$. francisci $(\mathrm{mg} / \mathrm{mL})$

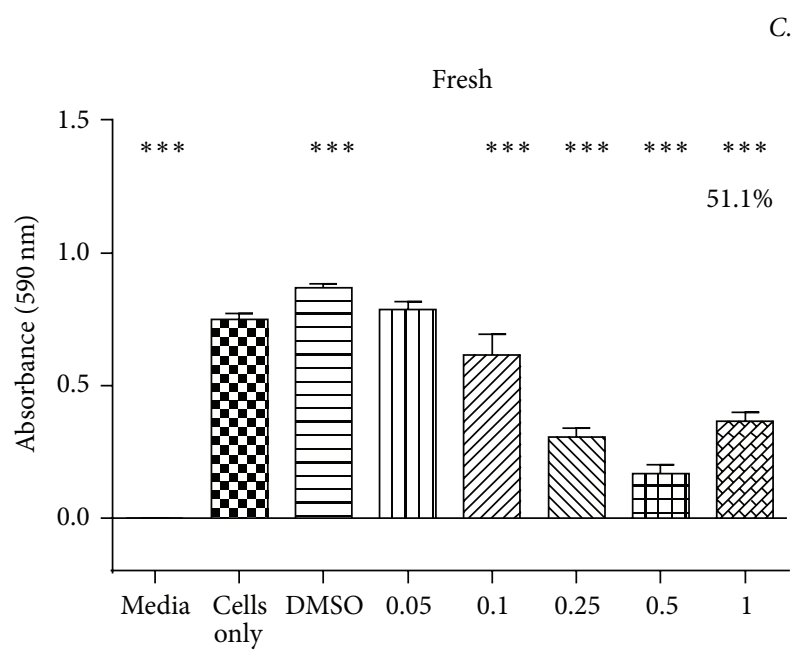

Concentration L. francisci $(\mathrm{mg} / \mathrm{mL})$

C. krusei

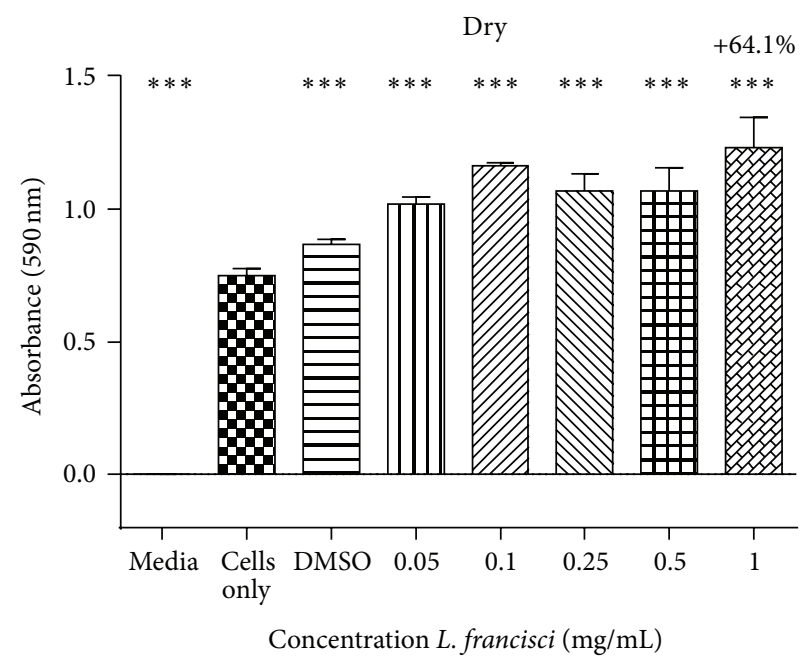

FIgURE 4: The effect of fresh and dry L. francisci ethanol extracts on the growth of Candida albicans and Candida krusei. Growth of the treated cells was compared to the growth of the untreated cells. Inhibition of C. albicans growth was seen at low concentrations of the fresh extract, while the dry extract as only effective at higher concentrations. The percentage reductions in growth at the $1 \mathrm{mg} / \mathrm{mL}$ are shown for both extracts. The fresh extract reduced the growth of $C$. krusei, while the dry extract encouraged the growth of $C$. krusei. The growth of $C$. krusei was reduced by $51.1 \%$ when treated with $1 \mathrm{mg} / \mathrm{mL}$ of the fresh extract but increased by $64.1 \%$ when treated with the dry extract at the same concentration. ${ }^{* *} P<0.001 ;{ }^{* * *} P<0.0001 . N=4$.

3.2.5. The Effects of the Fresh and Dry Aqueous Extracts. The effects of the fresh and dry aqueous extracts on the growth of Candida are shown in Figure 6. The aqueous extracts were dissolved in distilled water so no DMSO control was required. Against C. albicans, the fresh extract was only effective at $0.25 \mathrm{mg} / \mathrm{mL}$ and $1 \mathrm{mg} / \mathrm{mL}$ with growth inhibitions of $13.8 \%$ and $28.1 \%$. The dry extract inhibited growth of C. albicans significantly at $0.25 \mathrm{mg} / \mathrm{mL}$ and $1 \mathrm{mg} / \mathrm{mL}$. The fresh and dry aqueous extracts increased the growth of $C$. krusei in a dosedependent manner. When treated with the fresh extract, the increase in C. krusei growth ranged from 32.3\% to $104.7 \%$. The increase in growth of C. krusei when treated with the dry extract was at least $71.4 \%$. A summary of the results of the antifungal screening assay is shown in Table 1 . The results shown are the percentage inhibition of growth of $C$. albicans and C. krusei after treatment with $L$. francisci extracts. A "+" indicates growth stimulation.

\subsection{Determination of the Toxicity Properties of Lampranthus francisci}

3.3.1. Effect of L. francisci on the Haemolysis of Sheep Red Blood Cells. To determine the toxicity of $L$. francisci, fresh and dry hydroethanolic extracts were tested against sheep red blood cells. The results of the assay are shown in Figure 7. The haemolysis of the red blood cells after treatment with the extracts was expressed as a percentage of the positive control, whose haemolysis was considered to be $100 \%$. At $0.25 \mathrm{mg} / \mathrm{mL}$, 


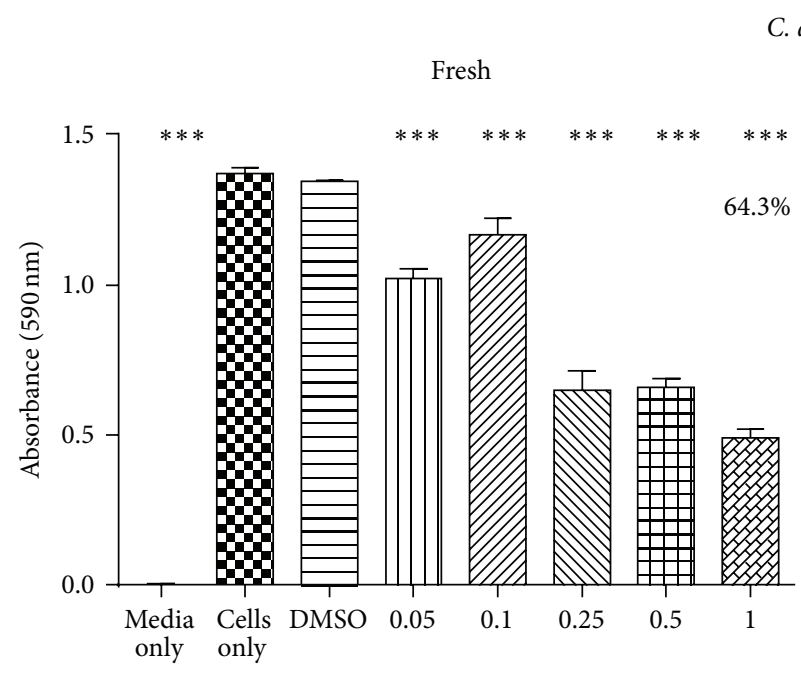

Concentration L. francisci $(\mathrm{mg} / \mathrm{mL})$

C. albicans

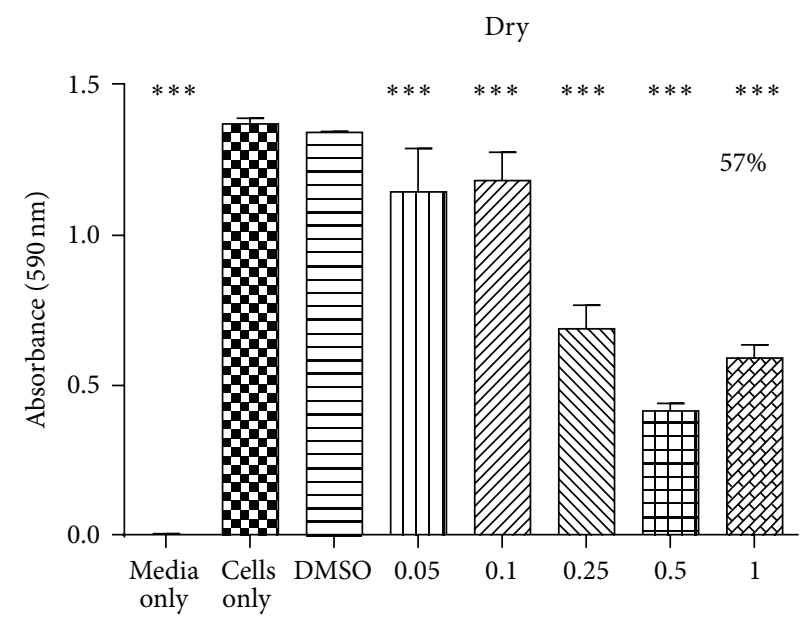

Concentration L. francisci $(\mathrm{mg} / \mathrm{mL})$

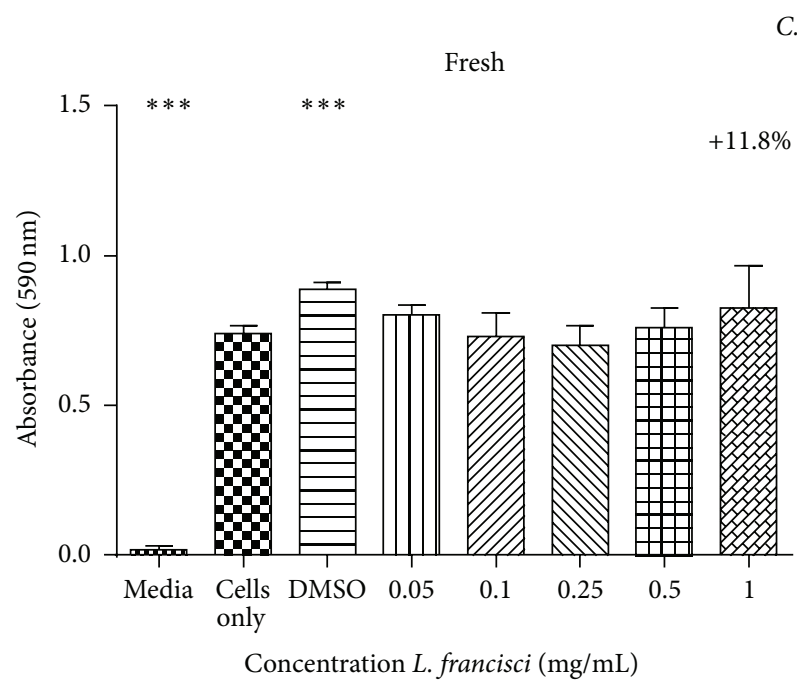

C. krusei

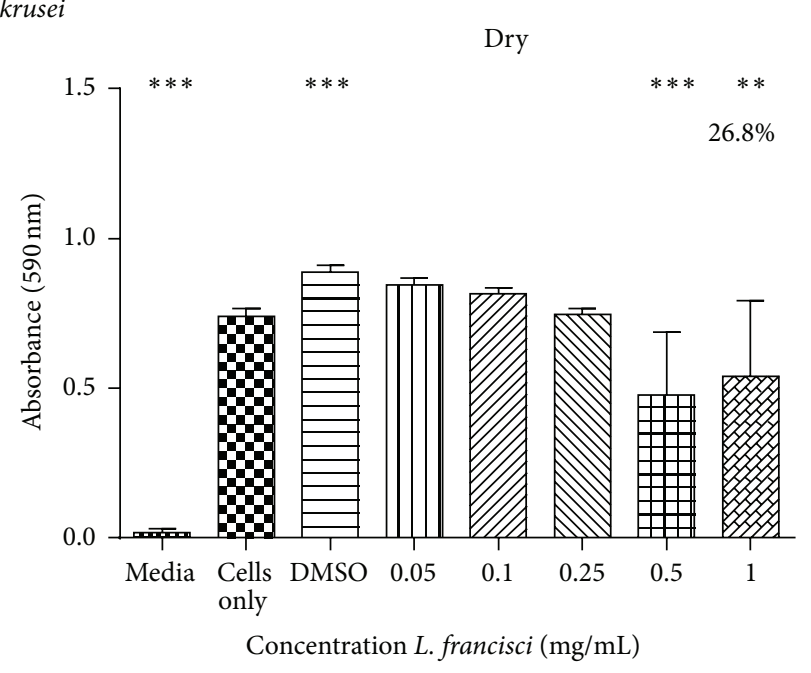

FIgURE 5: The effects of the fresh and dry L. francisci hydroethanolic extracts on the growth of Candida albicans and Candida krusei. Against C. albicans, a significant decrease in growth was observed at all tested concentrations of both extracts compared to the untreated cells. At $1 \mathrm{mg} / \mathrm{mL}$, the fresh extract inhibited growth by $63.4 \%$ while the dry extract inhibited growth by $57 \%$. The fresh extract had no effect on the growth of $C$. krusei, while the dry extract was only effective at high concentrations. The dry extract reduced the growth of $C$. $k r u s e i$ by $26.8 \%$ at $1 \mathrm{mg} / \mathrm{mL}$ compared to the untreated cells. ${ }^{* *} P<0.001 ;{ }^{* * *} P<0.0001 . N=4$.

$0.5 \mathrm{mg} / \mathrm{mL}$, and $1 \mathrm{mg} / \mathrm{mL}$ of the fresh extract, the haemolysis of the red blood cells was the same at $24 \%, 24 \%$, and $39 \%$, respectively. The dry extract caused haemolysis at $1 \mathrm{mg} / \mathrm{mL}$ only (24\%). The haemolysis of the untreated cells was $21 \%$.

\subsubsection{Effects of L. francisci Aqueous Extracts on the Growth} and Metabolic Activity of Mouse Peritoneal Cavity Cells. Mouse peritoneal cavity cells were used in addition to the sheep red blood cells as an in vitro model to determine the toxicity of $L$. francisci extracts. Two methods were used: a microplate assay using MTT to determine the effect of the extracts on the metabolic activity and a cell counting method using the trypan blue exclusion assay. Figures $8(a)$ and 8 (b) show the effects of the fresh and dry aqueous extracts on the metabolic activity and cell density of the mouse peritoneal cavity cells, respectively. At $1 \mathrm{mg} / \mathrm{mL}$, the fresh aqueous extract caused an $8.1 \%$ increase in the metabolic activity of the peritoneal cavity cells. The extract caused an increase in the number of cells in a dose-dependent manner. When treated with $1 \mathrm{mg} / \mathrm{mL}$ of the extract, the number of cells increased by $1891.2 \%$. The dry aqueous extract reduced metabolic activity by $17.5 \%$ and $92.3 \%$, respectively, at $0.5 \mathrm{mg} / \mathrm{mL}$ and $1 \mathrm{mg} / \mathrm{mL}$, respectively. The dry extract stimulated the growth of the cells in a dose-dependent manner.

3.3.3. The Effects of L. francisci Hydroethanolic Extracts on the Growth and Metabolic Activity of the Mouse Peritoneal Cavity Cells. Figures 9(a) and 9(b) show the effects of the L. francisci fresh and dry hydroethanolic extracts on the metabolic activity and growth of the mouse peritoneal cavity 


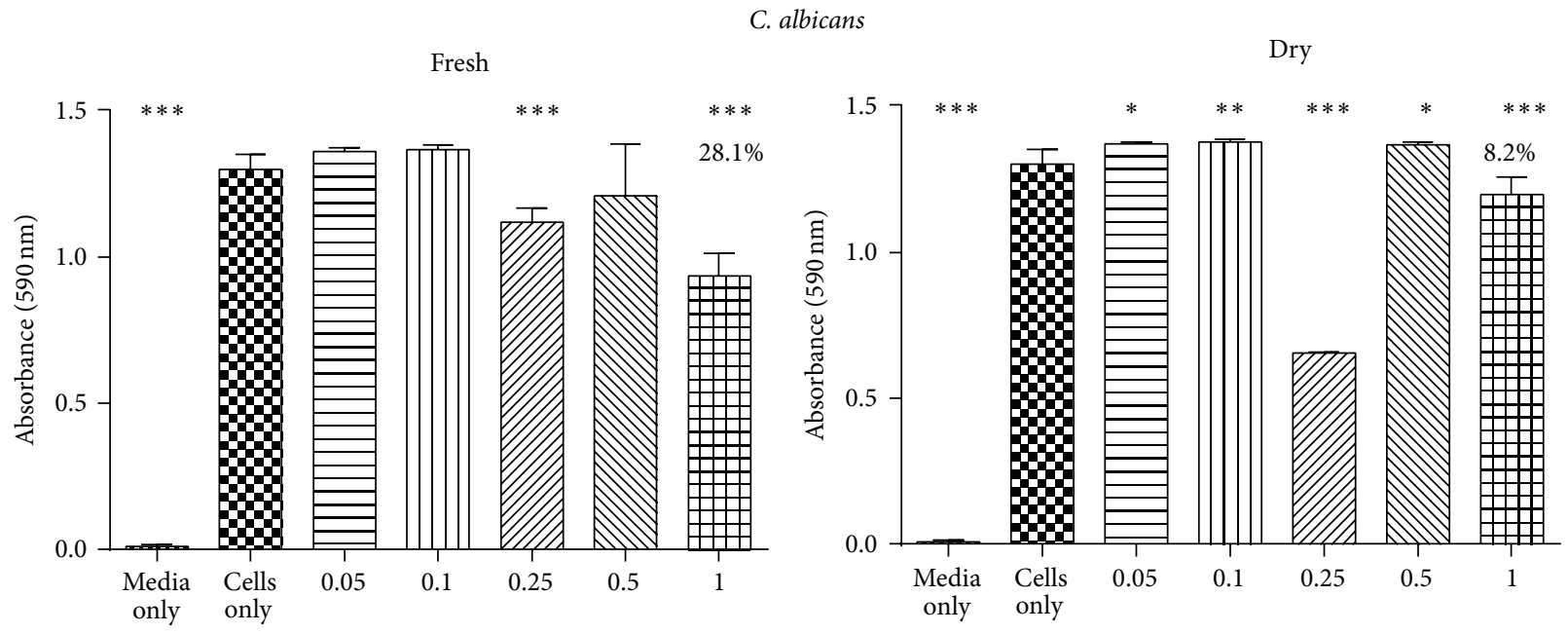

Concentration of $L$. francisci $(\mathrm{mg} / \mathrm{mL})$

Concentration of $L$. francisci $(\mathrm{mg} / \mathrm{mL})$

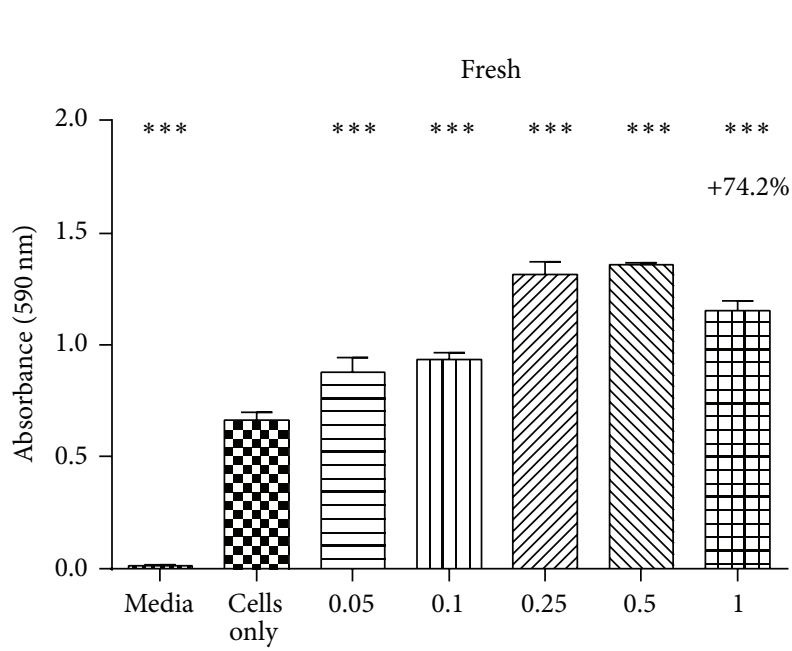

C. krusei

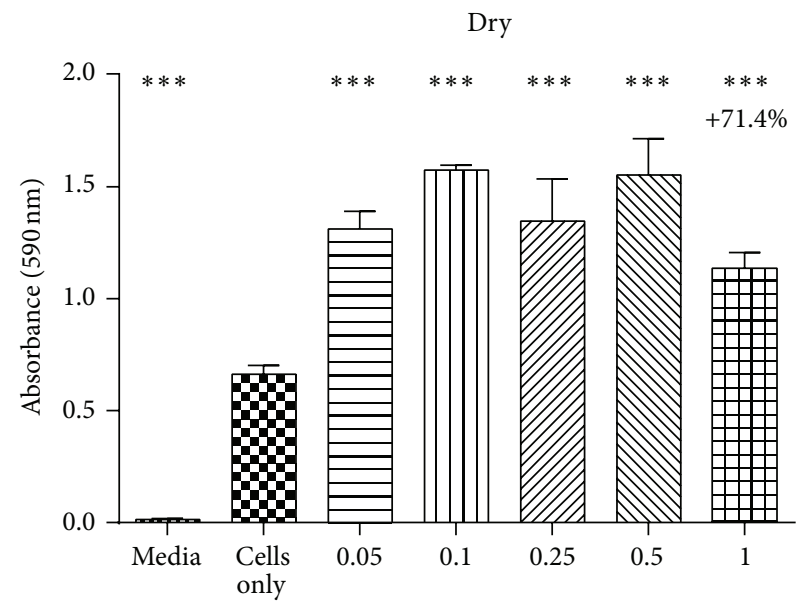

Concentration of $L$. francisci $(\mathrm{mg} / \mathrm{mL})$

Concentration of $L$. francisci $(\mathrm{mg} / \mathrm{mL})$

Figure 6: The effects of the fresh and dry aqueous extracts on the growth of Candida albicans and Candida krusei. The extracts inhibited the growth of C. albicans at some concentrations, while the dry extract was found to encourage growth at $0.05 \mathrm{mg} / \mathrm{mL}, 0.1 \mathrm{mg} / \mathrm{mL}$, and $0.5 \mathrm{mg} / \mathrm{mL}$. At $1 \mathrm{mg} / \mathrm{mL}$, the fresh and dry extracts reduced the growth of C. albicans by $28.1 \%$ and $8.2 \%$, respectively. Both extracts encouraged the growth of C. krusei, although the dry extract stimulated growth more than the fresh extract. At $1 \mathrm{mg} / \mathrm{mL}$, the effects of the fresh and dry extracts against C. krusei were similar as the increases in growth were $74.2 \%$ and $71.4 \%$, respectively. Growth of Candida at the tested concentrations was compared to the growth of the untreated cells. ${ }^{*} P<0.5 ;{ }^{* *} P<0.001 ;{ }^{* * *} P<0.0001 . N=4$.

TABLE 1: Summary of the antifungal activities of the L. francisci extracts. The table shows percentage decrease in fungal growth compared to the untreated control at the highest concentration of miconazole/plant extract expressed as a percentage. The highest concentration of miconazole was $100 \mu \mathrm{g} / \mathrm{mL}$, while that of the plant extracts was $1 \mathrm{mg} / \mathrm{mL}$. Where the growth increased, the growth is indicated by a "+." The results of drug accumulation are also shown, expressed as a percentage decrease in R6G accumulation compared to the cells treated with reserpine.

\begin{tabular}{|c|c|c|c|c|c|c|c|c|c|}
\hline & \multirow{2}{*}{$\operatorname{Mic}(\%)$} & \multicolumn{2}{|c|}{ Acetone (\%) } & \multicolumn{2}{|c|}{ Ethanol (\%) } & \multicolumn{2}{|c|}{ Hydroethanolic (\%) } & \multicolumn{2}{|c|}{ Aqueous (\%) } \\
\hline & & Fresh & Dry & Fresh & Dry & Fresh & Dry & Fresh & Dry \\
\hline C. albicans & 101 & 27.9 & 1.2 & 45.6 & 75.8 & 64.3 & 57 & 28.1 & 8.2 \\
\hline C. krusei & 104.7 & 37 & +100 & 51.1 & +64.1 & +11.8 & 26.8 & +74.2 & +71.4 \\
\hline
\end{tabular}

Mic: Miconazole. 


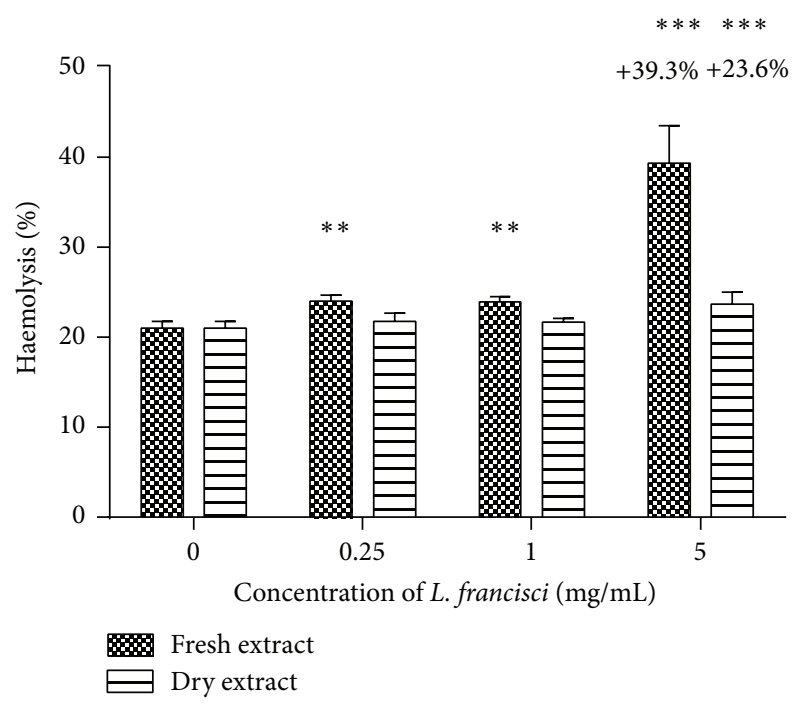

FIGURE 7: The effect of L. francisci fresh and dry hydroethanolic extracts on sheep red blood cells. Haemolysis was higher after treatment with the fresh extract than the dry extract. Haemolysis of the sheep red blood cells after treatment with the $L$. francisci extracts was compared to the untreated cells. ${ }^{* *} P<0.001 ;{ }^{* * *} P<0.0001$. $N=12$.

cells, respectively. The fresh extract increased the metabolic activity and the growth of the peritoneal cavity cells in a dose-dependent manner. The dry hydroethanolic extract increased the metabolic activity of the peritoneal cavity cells by $22.8 \%$ and $36.5 \%$ at $0.5 \mathrm{mg} / \mathrm{mL}$ and $1 \mathrm{mg} / \mathrm{mL}$, respectively. At $0.25 \mathrm{mg} / \mathrm{mL}$ and $0.5 \mathrm{mg} / \mathrm{mL}$ of the dry extract, the extract caused a $55.7 \%$ and $46.8 \%$ decrease in the number of live cells, respectively. A summary of the results of the study of the effects of $L$. francisci extracts on the growth and metabolic activity of mouse peritoneal cavity cells is shown in Table 2. The percentage decrease in cell metabolic activity (MTT) and cell density (trypan blue exclusion) is shown. A “+” indicates stimulatory activity.

\section{Discussion}

The rise in drug-resistant fungal infections has led to an urgent need for new antifungal agents. Eight L. francisci extracts were tested against C. albicans and C. krusei to determine their antifungal activity. DMSO was used to dissolve the acetone, ethanol, and hydroethanolic extracts, while the aqueous extracts were dissolved in water as they were incapable of dissolving in DMSO. DMSO is a polar solvent that has the ability to dissolve a wide range of compounds and is miscible with most solvents [45]. Zutz et al. [46] found that DMSO up to a concentration of $2.5 \%$ did not alter the growth of C. albicans. In this study, DMSO was used at a final concentration of $3 \%$ and it was noted it had a growth stimulatory effect at all tested concentrations on C. krusei only. C. krusei is used in bioremediation [47]. The use of $C$. krusei in bioremediation may explain the ability of the fungus to grow in the presence of organic solvents. Miconazole, an imidazole, is a standard antifungal agent that is used to treat superficial mycoses [48]. Miconazole works by preventing the synthesis of ergosterol and inhibiting peroxidases [49]. Miconazole was effective against C. albicans and C. krusei. C. krusei was more susceptible to miconazole than C. albicans at lower concentrations. In the literature, miconazole has been found to be effective against C. albicans and C. krusei [48].

Activity against $C$. albicans was observed upon treatment with all of the extracts except the dry acetone and aqueous extracts. The dry acetone extract had no effect on the $C$. albicans cells at all tested concentrations. The lack of activity may have been due to the active compounds being volatile resulting in the loss of these compounds during the drying of the $L$. francisci leaves. Drying plant material may result in degradation of the phytoconstituents in the plant [50]. For instance, dried leaves of Calendula officinalis did not contain some compounds that were present in the fresh leaves [51]. Some authors prefer using fresh plant parts as the compounds in the plant remain in their active state [52].

The hydroethanolic extracts were the most effective against C. albicans at low concentrations. At $0.1 \mathrm{mg} / \mathrm{mL}$ and $0.25 \mathrm{mg} / \mathrm{mL}$, the fresh ethanol extract was more effective than the dry extract against C. albicans, while at $0.5 \mathrm{mg} / \mathrm{mL}$ and $1 \mathrm{mg} / \mathrm{mL}$, the dry extract was more effective. The fresh extract may, thus, be considered to be more effective than the dry extract overall as greater antifungal activity is seen at lower concentrations. The $L$. francisci fresh ethanol extract was the most effective extract against C. krusei, followed by the fresh acetone extract. When C. krusei was treated with the fresh ethanol extract, fresh acetone extract, and the fresh and dry hydroethanolic extracts, a growth in cell density was observed from $0.5 \mathrm{mg} / \mathrm{mL}$ to $1 \mathrm{mg} / \mathrm{mL}$. Increasing the concentration of extract may have increased the amount of nutrients available to the Candida and, thus, resulted in an increase in growth as the C. krusei were able to overcome the negative effects of the extracts.

The aqueous extracts were not very effective against C. albicans, particularly the dry extract as it encouraged the growth of $C$. albicans. This means that these extracts most likely did not contain any antifungal compounds. The hydroethanolic fresh extract had no effect on the growth of C. krusei. The dry ethanol extract, dry acetone extract, and the fresh and dry aqueous extracts promoted the growth of C. krusei. These extracts are, thus, not recommended for use against $C$. krusei infections.

The extracts had differing activities against C. albicans and C. krusei. Differences in the cell structure of the two fungi may explain the observed results. C. albicans have $\alpha-\mathrm{D}$ mannan with a (1-6)-linked backbone that has (1-2) and/or (1-3) linkages on the side chains, while C. krusei is composed of 2- and 6-linkage [14]. Different metabolic pathways and drug efflux pumps may be responsible for the observed differences in activity, for example, C. krusei is only capable of using glucose as a carbohydrate source while C. albicans can use many different sugars [14].

Fungi and humans are both eukaryotic and as a result, finding antifungal agents that are nontoxic to humans but active against fungi may be difficult [53]. The effect of $L$. francisci on the haemolysis of sheep red blood cells was investigated. Red blood cells are important as they are used 

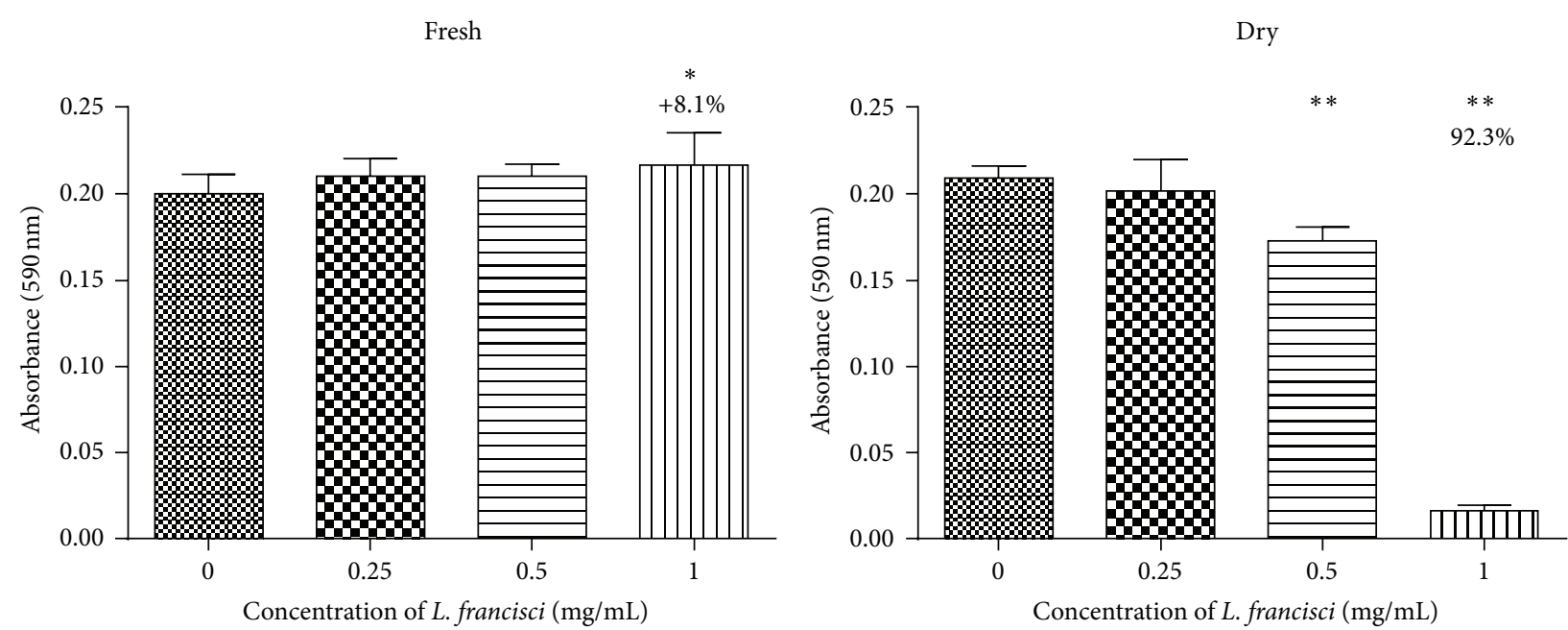

(a)
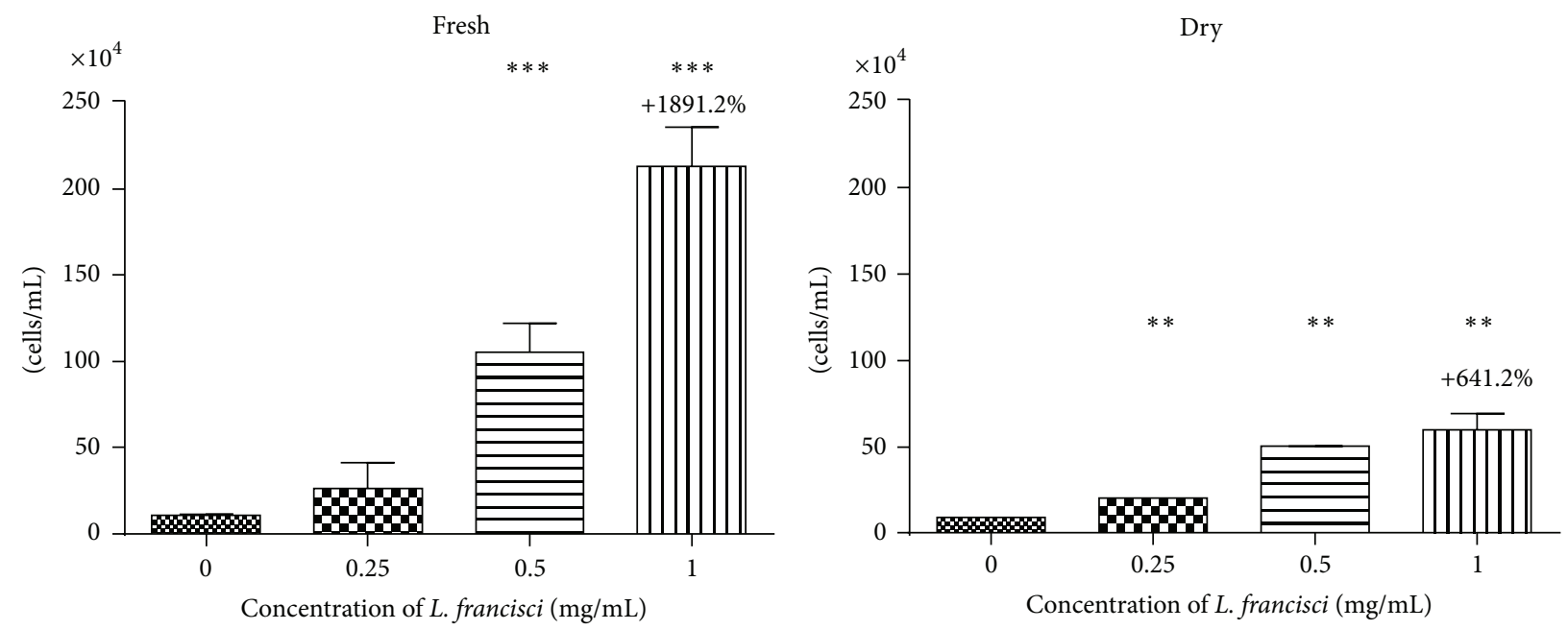

(b)

Figure 8: The effects of the fresh and dry aqueous L. francisci extracts on mouse peritoneal cavity cells. (a) and (b) show the effects of the extracts on the metabolic activity and the cell density, respectively, of the mouse peritoneal cavity cells. In (a), the fresh extract had no effect on the peritoneal cavity cells at low concentrations, while the dry extract decreased the metabolic activity of the peritoneal cavity cells at $0.5 \mathrm{mg} / \mathrm{mL}$ and $1 \mathrm{mg} / \mathrm{mL}$. The percentage increase or decrease of the metabolic activity of mouse peritoneal cavity cells due to the effect of the fresh and dry extracts, respectively, at $1 \mathrm{mg} / \mathrm{mL}$ is shown. In (b), the effects of $L$. francisci fresh and dry aqueous extracts on the growth of mouse peritoneal cavity cells as determined using the trypan blue exclusion method. The extracts promoted the growth of the mouse peritoneal cavity cells. The percentage increases at the highest concentrations of each extract are shown on the graph. ${ }^{*} P<0.5$; ${ }^{* *} P<0.001$; ${ }^{* * *} P<0.0001$.

to carry oxygen around the body [54]. This assay of cytotoxic activity is extremely sensitive to a wide range of xenobiotics and may be due to any number of the phytochemicals within the crude plant extract. Reduced numbers of red blood cells can result in oxygen depletion leading to serious illness. The fresh hydroethanolic extract was toxic at all tested concentrations as increases in haemolysis of 3\%, 3\%, and 39\% compared to the control sample were detected at $0.25 \mathrm{mg} / \mathrm{mL}$, $1 \mathrm{mg} / \mathrm{mL}$, and $5 \mathrm{mg} / \mathrm{mL}$, respectively. The fresh extract was, thus, considered toxic against sheep red blood cells. The dry extract was toxic against the sheep red blood cells at $5 \mathrm{mg} / \mathrm{mL}$ only. The dry extract was active against C. albicans and C. krusei at concentrations up to $1 \mathrm{mg} / \mathrm{mL}$, at which the extract is nontoxic against the sheep red blood cells. These results are encouraging as having an extract that is nontoxic but active against a pathogen is necessary. Artemisia dracunculus, Cuminum cyminum, and Heracleum persicum are plants whose extracts were found to cause haemolysis [55]. Croton zambesicus and Xylopia aethiopica have haemoprotective properties [56]. Khalili et al. [57] investigated 30 plant extracts for haemolytic activity. Cucumis melo, Albizia julibrissin, and Orobanche orientalis were found to have haemolytic activity, while Sambucus ebulus, Galium verum, and Scutellaria tournefortii had haemoprotective activity as these plant extracts decreased the lysis of red blood cells compared to the control [57]. 

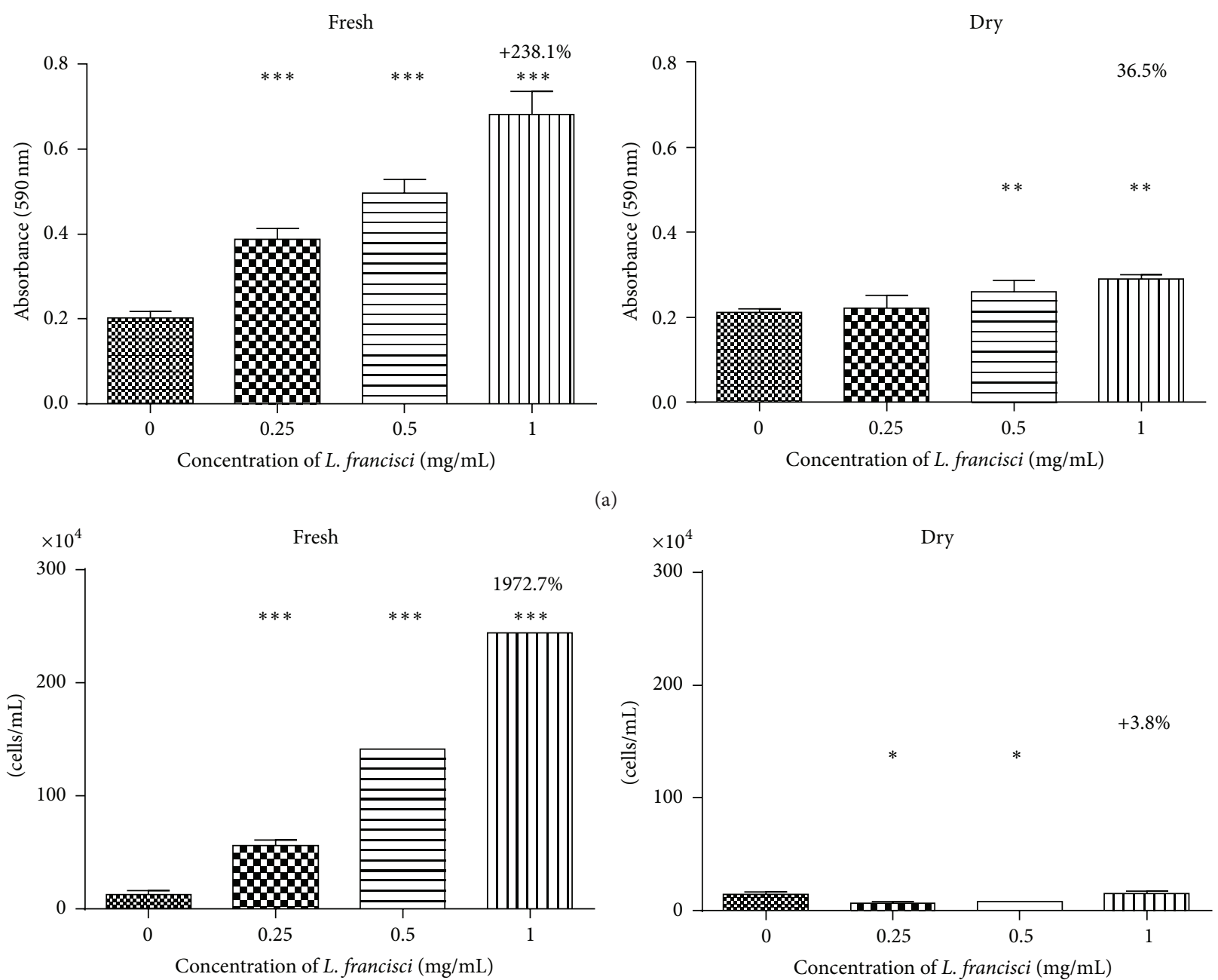

(b)

FIGURE 9: Effects of fresh and dry L. francisci hydroethanolic extracts on the mouse peritoneal cavity cells. (a) and (b) show the effects of the extracts on the metabolic activity and the cell density, respectively, of the mouse peritoneal cavity cells. In (a), the fresh extract significantly increased the metabolic activity of the mouse peritoneal cavity cells. The dry extract only increased the metabolic activity at $0.5 \mathrm{mg} / \mathrm{mL}$ and $1 \mathrm{mg} / \mathrm{mL}$. The percentage increase in the metabolic activity of the cells at $1 \mathrm{mg} / \mathrm{mL}$ of the extracts is shown on the graph. In (b), the effects of the fresh and dry L. francisci hydroethanolic extracts on the growth of the mouse peritoneal cavity cells as determined using the trypan blue exclusion assay are shown. The fresh extract promoted the growth of the cells while the dry extract had no growth stimulatory effect. ${ }^{*} P<0.05 ;{ }^{* *} P<0.001 ;{ }^{* *} P<0.0001$.

TABLE 2: The effects of $L$. francisci on mouse peritoneal cavity cells. The figures show the percentage decrease in the number or metabolic activity of the mouse peritoneal cavity cells after treatment with $L$. francisci extracts. A “+” indicates an increase in cell density or metabolic activity. The MTT assay measured metabolic activity, while the trypan blue exclusion assay measured cell density in cells/mL.

\begin{tabular}{lcccc}
\hline & \multicolumn{2}{c}{ Aqueous extracts (\%) } & \multicolumn{2}{c}{ Hydroethanolic extracts (\%) } \\
& Fresh & Dry & Fresh & Dry \\
\hline Cell & +8.1 & 92.3 & +238.1 & +36.5 \\
metabolism & & & & +1971.7 \\
Cell density & +1891.2 & +641.2 & +3.8 \\
\hline
\end{tabular}

The effect of the extracts on Balb/c mice peritoneal cavity cells was investigated. Mice are ideal model organisms as they are able to develop diseases such as cancer, diabetes, and hypertension like humans [53]. Mutations can be induced to encourage the development of diseases that these animals do not suffer from [53]. The effect of $L$. francisci hydroethanolic and aqueous extracts was determined in order to determine if the extract had any immune stimulatory activity. There were variations in the results obtained according to whether it is the trypan blue exclusion assay or the MTT assay. Correlation in the results obtained between the two methods was only observed with the fresh hydroethanolic extract. It was, therefore, concluded that the hydroethanolic fresh 
leaf extract stimulated cell growth and metabolic activity. At $1 \mathrm{mg} / \mathrm{mL}$ of the extract, the metabolic activity of the peritoneal cells increased by $138 \%$, while the cell counts increased by almost $1872.7 \%$. The dry hydroethanolic extract increased metabolic activity by $36.5 \%$ at $1 \mathrm{mg} / \mathrm{mL}$, while the cell density remained unchanged. The fresh aqueous extract did not increase metabolic activity but encouraged cell proliferation, while the dry extract decreased metabolic activity by $92.3 \%$ while increasing the cell density by $541 \%$. The differences in the results are most likely due to the differences in the methods used. The MTT measures the metabolic activity of cells that are metabolically active, but not proliferation [58]. The result obtained is influenced by the length of incubation, the MTT concentration, and the number and the metabolic activity of the live cells [58]. The MTT colour change must be measured at the most active stage of cell proliferation to reduce false positives and negatives [59]. The trypan blue exclusion assay is an assay in which cells are mixed with trypan blue solution. The live cells exclude the dye while dead cells take up the dye and are seen as blue cells under the microscope. The cell counting method distinguishes between live and dead cells but does not show cells that are beginning to lose their functions [60]. A disadvantage of the cell counting method is that the method is subjective [60]. Testing the effects of the extracts on mouse peritoneal cavity cells allowed an investigation into the toxicity of $L$. francisci as well as its immune stimulatory activity. The hydroethanolic fresh and dry extracts were found to stimulate the growth and metabolic activity of the peritoneal cavity cells. The aqueous extract was not effective at stimulating metabolic activity but increased the density of the mouse peritoneal cavity cells. The aqueous extracts also stimulated growth of the mouse peritoneal cavity cells according to the trypan blue exclusion assay method.

Assanga et al. [60] observed differences in the results obtained using the MTT and trypan blue exclusion assays. In their study, the cell counting method showed exponential growth of cells from $50 \mathrm{~h}$ of incubation, while the MTT assay only registered exponential growth at $2 \mathrm{~h}$ [60]. The authors concluded that although the MTT assay was less likely to have experimental errors and increased standard deviations, the assay could not be used to determine cell morphology [60]. Cell morphology is an excellent way to determine the effect of a compound on cells. Cell morphology can only be determined using a microscope as is done in the trypan blue exclusion assay. Using both methods in cell studies is an advantage as the metabolic activity can be measured in addition to determining the number of live cells.

\section{Conclusions}

L. francisci extracts showed a dose-dependent activity against C. albicans and C. krusei and was found to be more effective against C. albicans than C. krusei. L. francisci aqueous and hydroethanolic fresh extracts had immune stimulatory activity, suggesting that its constituents may be useful leads for drugs that stimulate the immune system especially for people with compromised immune systems.

\section{Conflict of Interests}

The authors declare that there is no conflict of interests regarding the publication of this paper.

\section{Acknowledgments}

The authors acknowledge the assistance by Mr. Christopher Chapano, a taxonomist with the National Herbarium and Botanical Gardens (Harare, Zimbabwe). The authors also thank Dr. V. Robertson (Department of Medical Microbiology, University of Zimbabwe) for supplying them with Candida krusei. This study was sponsored by the International Science Programmes (ISP), through the International Program in the Chemical Sciences (IPICS: ZIM01), Uppsala University, Uppsala, Sweden. Support from the University of Zimbabwe Research Board is also acknowledged.

\section{References}

[1] D. M. Khan, L. Bernaitis, K. L. Shobha, M. Ashok, and R. P. Shenoy, "Antifungal activity of Taxus baccata, Phyllanthus debilis, Plectranthus amboinicus against Candida species of clinical origin," International Journal of Biological \& Pharmaceutical Research, vol. 4, no. 5, pp. 386-389, 2013.

[2] H. F. Jenkinson and L. J. Douglas, Polymicrobial Diseases, ASM Press, Washington, DC, USA, 2002.

[3] V. Mohandas and M. Ballal, "Distribution of Candida species in different clinical samples and their virulence: biofilm formation, proteinase and phospholipase production: a study on hospitalized patients in Southern India," Journal of Global Infectious Diseases, vol. 3, no. 1, pp. 4-8, 2011.

[4] C. J. Walraven and S. A. Lee, "Antifungal lock therapy," Antimicrobial Agents and Chemotherapy, vol. 57, no. 1, pp. 1-8, 2013.

[5] C.-Y. Low and C. Rotstein, "Emerging fungal infections in immunocompromised patients," F1000 Medicine Reports, vol. 3, article 14, 2011.

[6] J. C. O. Sardi, L. Scorzoni, T. Bernardi, A. M. Fusco-Almeida, and M. J. S. Mendes Giannini, "Candida species: current epidemiology, pathogenicity, biofilm formation, natural antifungal products and new therapeutic options," Journal of Medical Microbiology, vol. 62, no. 1, pp. 10-24, 2013.

[7] S. G. D. Oliveira, P. S. Nascente, J. J. H. Escareño, R. V. Carvalho, E. Piva, and R. G. Lund, "Evaluation of anti-Candida activity and cytotoxicity of Jatropha dioica Cerv. extracts," African Journal of Microbiology Research, vol. 7, no. 30, pp. 3903-3907, 2013.

[8] M. E. Brandt and B. J. Park, "Think fungus-prevention and control of fungal infections," Emerging Infectious Diseases, vol. 19, no. 10, pp. 1688-1689, 2013.

[9] J. R. de Oliveira, V. C. de Castro, P. D. G. F. Vilela et al., "Cytotoxicity of Brazilian plant extracts against oral microorganisms of interest to dentistry," BMC Complementary and Alternative Medicine, vol. 13, article 208, 2013.

[10] T. Fukuoka, D. A. Johnston, C. A. Winslow et al., "Genetic basis for differential activities of fluconazole and voriconazole against Candida krusei," Antimicrobial Agents and Chemotherapy, vol. 47, no. 4, pp. 1213-1219, 2003.

[11] G. Vediyappan, V. Dumontet, F. Pelissier, and C. d'Enfert, "Gymnemic acids inhibit hyphal growth and virulence in Candida albicans," PloS one, vol. 8, no. 9, Article ID e74189, 2013. 
[12] R. D. Cannon, E. Lamping, A. R. Holmes et al., "Efflux-mediated antifungal drug resistance," Clinical Microbiology Reviews, vol. 22, no. 2, pp. 291-321, 2009.

[13] C. J. Heilmann, A. G. Sorgo, S. Mohammadi et al., "Surface stress induces a conserved cell wall stress response in the pathogenic fungus Candida albicans," Eukaryotic Cell, vol. 12, no. 2, pp. 254264, 2013.

[14] Y. H. Samaranayake and L. P. Samaranayake, "Candida krusei: biology, epidemiology, pathogenicity and clinical manifestations of an emerging pathogen," Journal of Medical Microbiology, vol. 41, no. 5, pp. 295-310, 1994.

[15] M. A. Pfaller, "Antifungal drug resistance: mechanisms, epidemiology, and consequences for treatment," The American Journal of Medicine, vol. 125, pp. S3-S13, 2012.

[16] Y. F. Berrouane, R. J. Hollis, and M. A. Pfaller, "Strain variation among and antifungal susceptibilities of isolates of Candida krusei," Journal of Clinical Microbiology, vol. 34, no. 7, pp. 18561858, 1996.

[17] J. S. S. Yadav, J. Bezawada, S. Yan, R. D. Tyagi, and R. Y. Surampalli, "Candida krusei: biotechnological potentials and concerns about its safety," Canadian Journal of Microbiology, vol. 58, no. 8, pp. 937-952, 2012.

[18] L. Scorzoni, M. P. de Lucas, A. C. Mesa-Arango et al., "Antifungal Efficacy during Candida krusei Infection in nonconventional models correlates with the yeast in vitro susceptibility profile," PLoS ONE, vol. 8, no. 3, Article ID e60047, 2013.

[19] P. G. Pappas, J. H. Rex, J. D. Sobel et al., "Guidelines for treatment of candidiasis," Clinical Infectious Diseases, vol. 38, no. 2, pp. 161-189, 2004.

[20] R. D. Cannon, E. Lamping, A. R. Holmes et al., "Candida albicans drug resistance-another way to cope with stress," Microbiology, vol. 153, no. 10, pp. 3211-3217, 2007.

[21] J. P. Dzoyem, R. T. Tchuenguem, J. R. Kuiate, G. N. Teke, F. A. Kechia, and V. Kuete, "In Vitro and In Vivo antifungal activities of selected Cameroonian dietary spices," BMC Complementary and Alternative Medicine, vol. 14, article 58, 2014.

[22] O. A. Alabi, M. T. Haruna, C. P. Anokururu et al., "Comparative studies on antimicrobial properties of extracts of fresh and dried leaves of Carica papaya on clinical bacteria and fungal isolates," Advances in Applied Science Research, vol. 3, no. 5, pp. 3107-3114, 2012.

[23] M. F. Balandrin, A. D. Kinghorn, and N. R. Farnsworth, PlantDerived Natural Products in Drug Discovery and Development, Human Medicinal Agents from Plants, American Chemical Society, Washington, DC, USA, 1993.

[24] C. Veeresham, "Natural products derived from plants as a source of drugs," Journal of Advanced Pharmaceutical Technology and Research, vol. 3, no. 4, pp. 200-201, 2012.

[25] A. Pandey and S. Tripathi, "Concept of standardization, extraction and phytochemical screening strategies for herbal drug," Journal of Pharmacognosy and Phytochemistry, vol. 2, no. 5, pp. 115-119, 2014.

[26] N. M. Hasan and M. K. Al Sorkhy, "Herbs that promote cell proliferation," International Journal of Herbal Medicine, vol. 1, no. 6, pp. 18-21, 2014.

[27] S. K. Yeap, A. R. Omar, A. M. Ali, W. Y. Ho, B. K. Beh, and N. B. Alitheen, "Immunomodulatory effect of Rhaphidophora korthalsii on natural killer cell cytotoxicity," Evidence-Based Complementary and Alternative Medicine, vol. 2012, Article ID 786487, 7 pages, 2012.
[28] N. Kodama, K. Komuta, N. Sakai, and H. Nanba, "Effects of D-fraction, a polysaccharide from Grifola frondosa on tumor growth involve activation of NK cells," Biological and Pharmaceutical Bulletin, vol. 25, no. 12, pp. 1647-1650, 2002.

[29] F.-S. Chueh, J.-J. H. Lin, J.-H. Lin, S.-W. Weng, Y. I.-P. Huang, and J.-G. Chung, "Crude extract of Polygonum cuspidatum stimulates immune responses in normal mice by increasing the percentage of Mac-3-positive cells and enhancing macrophage phagocytic activity and natural killer cell cytotoxicity," Molecular Medicine Reports, vol. 11, no. 1, pp. 127-132, 2015.

[30] V. S. Neergheen-Bhujun, "Underestimating the toxicological challenges associated with the use of herbal medicinal products in developing countries," BioMed Research International, vol. 2013, Article ID 804086, 9 pages, 2013.

[31] M. M. Eddouks and M. D. Ghanimi, "The use of medicinal plants in human healthcare: a scoop of safety," Pharmaceutical Regulatory Affairs Journal, vol. 3, article e122, 2013.

[32] The Global Biodiversity Information Facility: GBIF Backbone Taxonomy (1), Lampranthus francisci L. Bolus, 2013, http:// www.gbif.org/species/3705696.

[33] The Global Biodiversity Information Facility: GBIF Backbone Taxonomy, "Aizoaceae Martinov," 2013, http://www.gbif.org/ species/6752.

[34] Delange, “Ice Plant, Lampranthus spectabilis," 2015, http://www .delange.org/IcePlant/IcePlant.htm.

[35] R. Mohammed, S. S. El-Mawary, and A. M. Abo-Youssef, "Biological investigation of some wild Aizoaceae and Chenopediaceae species growing in Egypt," Journal of Natural Products, vol. 5, pp. 193-206, 2012.

[36] B. E. Omoruyi, A. J. Afolayan, and G. Bradley, "The inhibitory effect of Mesembryanthemum edule (L.) bolus essential oil on some pathogenic fungal isolates," BMC Complementary and Alternative Medicine, vol. 14, article 168, 2014.

[37] S. Abd-Ellatif, S. M. A. Rahman, and S. F. Deraz, "Promising antifungal effect of some folkloric medicinal plants collected from El-Hammam habitat, Egypt against dangerous pathogenic and toxigenic fungi," APRN Journal of Agricultural and Biological Science, vol. 6, no. 9, pp. 25-32, 2011.

[38] H. Falleh, N. Trabelsi, M. Bonenfant-Magné et al., "Polyphenol content and biological activities of Mesembryanthemum edule organs after fractionation," Industrial Crops and Products, vol. 42, no. 1, pp. 145-152, 2013.

[39] F. Delgado-Vargas and O. Paredes-López, Natural Colorants for Food and Nutraceutical Uses, CRC Press, Washington, DC, USA, 2000.

[40] California State Parks, "Ice plant," 2009, http://www.parks.ca .gov/pages/23071/files/iceplant\%203up\%20final.pdf.

[41] J. V. C. Orsine, R. V. da Costa, R. C. da Silva, M. F. M. A. Santos, and M. R. C. G. Novaes, "The acute cytotoxicity and lethal concentration $\left(\mathrm{LC}_{50}\right)$ of Agaricus sylvaticus through haemolytic activity on human erythrocytes," Journal of Nutrition and Metabolism, vol. 4, no. 11, pp. 19-23, 2012.

[42] A. Ray and B. N. Dittel, "Isolation of mouse peritoneal cavity cells," Journal of Visualized Experiments, no. 35, Article ID e1488, 2010.

[43] P. P. Saha, T. Bhowmik, A. K. Dasgupta, and A. Gomes, "In vivo and in vitro toxicity of nanogold conjugated snake venom protein toxin GNP-NKCT1," Toxicology Reports, vol. 1, pp. 7484, 2014.

[44] J. van Meerloo, G. J. L. Kaspers, and J. Cloos, "Cell sensitivity assays: the MTT assay," Methods in Molecular Biology, vol. 731, pp. 237-245, 2011. 
[45] T. Clark, J. S. Murray, P. Lane, and P. Politzer, "Why are dimethyl sulfoxide and dimethyl sulfone such good solvents?" Journal of Molecular Modeling, vol. 14, no. 8, pp. 689-697, 2008.

[46] C. Zutz, D. Bandian, B. Neumayer et al., "Fungi treated with small chemicals exhibit increased antimicrobial activity against facultative bacterial and yeast pathogens," BioMed Research International, vol. 2014, Article ID 540292, 13 pages, 2014.

[47] J. S. S. Yadav, J. Bezawada, S. Yan, R. D. Tyagi, and R. Y. Surampalli, "Candida krusei: biotechnological potentials and concerns about its safety," Canadian Journal of Microbiology, vol. 58, no. 8, pp. 937-954, 2012.

[48] M. Zarrin, M. Jamshidian, and M. Jafari, "In vitro interactions of miconazole with sulfametoxazole against Candida species," Pakistan Journal of Medical Sciences, vol. 25, no. 2, pp. 243-246, 2009.

[49] A. W. Fothergill, "Miconazole: a historical perspective," Expert Review of Anti-Infective Therapy, vol. 4, no. 2, pp. 171-175, 2006.

[50] G. Ponmari, R. Sathishkumar, P. T. V. lakshmi, and A. Annamalai, "Effect of drying treatment on the contents of antioxidants in Cardiospermum halicacabum Linn," International Journal of Pharma and Bio Sciences, vol. 2, no. 1, pp. 304-313, 2011.

[51] O. O. Okoh, A. P. Sadimenko, O. T. Asekun, and A. J. Afolayan, "The effects of drying on the chemical components of essential oils of Calendula officinalis L.", African Journal of Biotechnology, vol. 7, no. 10, pp. 1500-1502, 2008.

[52] A. A. H. S. Al-Janabi, "Comparison of fresh with dry extracts for antibacterial activity of Vigna radiate L. on pathogenic bacteria," Pharmacognosy Journal, vol. 2, no. 16, pp. 34-37, 2010.

[53] G. Spencer, "Background on Mouse as a Model Organism," 2002, http://www.genome.gov/10005834.

[54] T. Gersten, "Red blood cell production," 2013, http://www .nlm.nih.gov/medlineplus/ency/anatomyvideos/000104.htm.

[55] G. D. Noudeh, F. Sharififar, M. Khatib, E. Behravan, and M. A. Afzadi, "Study of aqueous extract of three medicinal plants on cell membrane-permeabilizing and their surface properties," African Journal of Biotechnology, vol. 9, no. 1, pp. 110-116, 2010.

[56] C. T. Avaligbe, J. D. Gbenou, D. S. S. Kpoviessi, G. C. Accrombessi, M. Moudachirou, and M. Gbeassor, "Antihemolytic properties of extracts of six plants used in the traditional treatment of sickle cell disease in Benin," Journal of Applied Pharmaceutical Science, vol. 2, no. 3, pp. 8-13, 2012.

[57] M. Khalili, M. A. Ebrahimzadeh, and Y. Safdari, "Antihaemolytic activity of thirty herbal extracts in mouse red blood cells," Archives of Industrial Hygiene and Toxicology, vol. 65, no. 4, pp. 399-406, 2014.

[58] T. L. Riss, R. A. Moravec, A. L. Niles, H. A. Benink, T. J. Worzella, and L. Minor, "Cell Viability Assays," 2015, http://www.ncbi.nlm .nih.gov/books/NBK144065/pdf/mttassays.pdf.

[59] S. A. Altman, L. Renders, and G. Rao, "Comparison of trypan blue dye exclusion and fluorometric assays for mammalian cell viability determinations," Biotechnology Progress, vol. 9, no. 6, pp. 671-674, 1993.

[60] I. S. B. Assanga, A. A. Gil-Salido, L. L. M. Luán et al., "Cell growth curves for different cell lines and their relationship with biological activities," International Journal for Biotechnology and Molecular Biology Research, vol. 4, no. 4, pp. 60-70, 2013. 

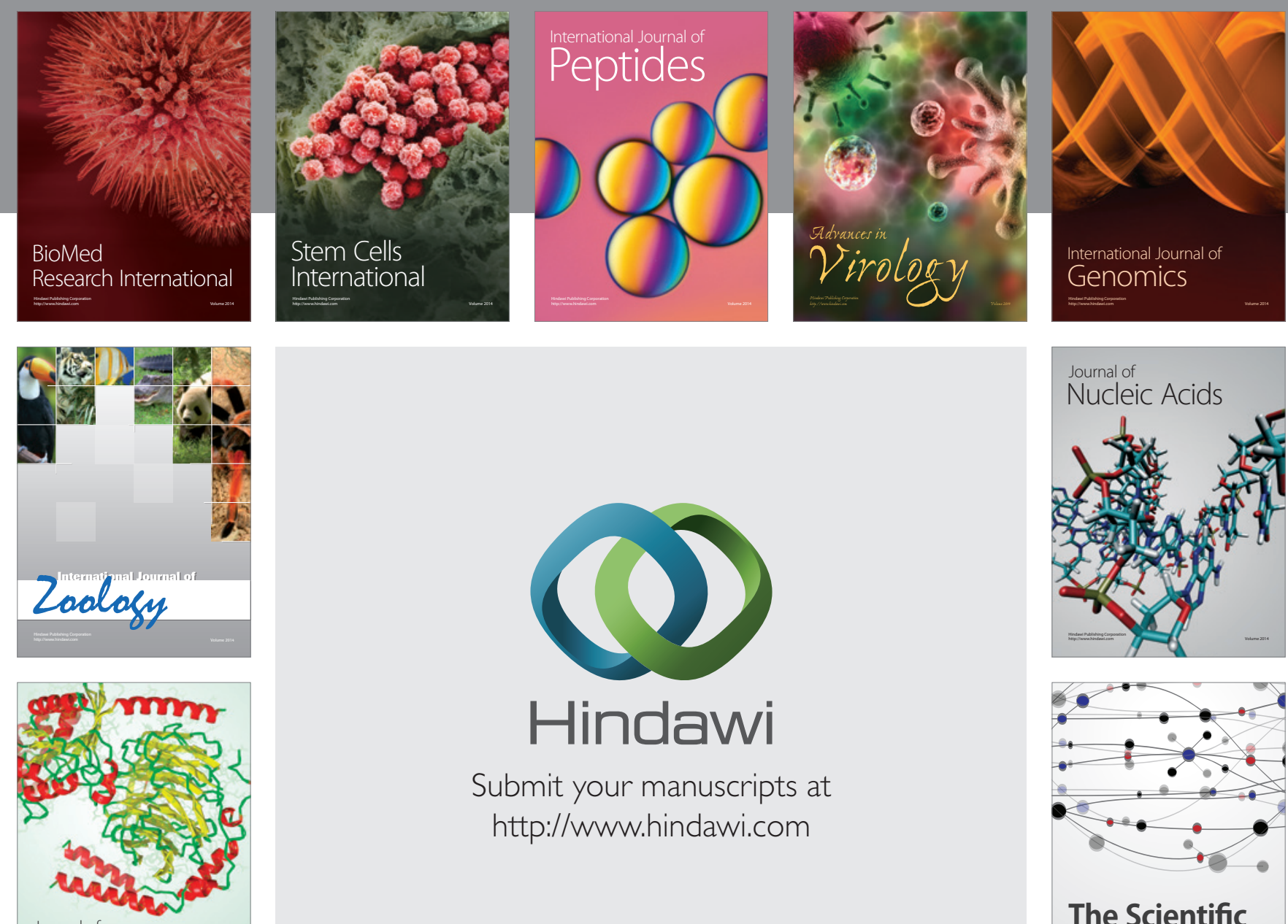

Submit your manuscripts at

http://www.hindawi.com

Journal of
Signal Transduction
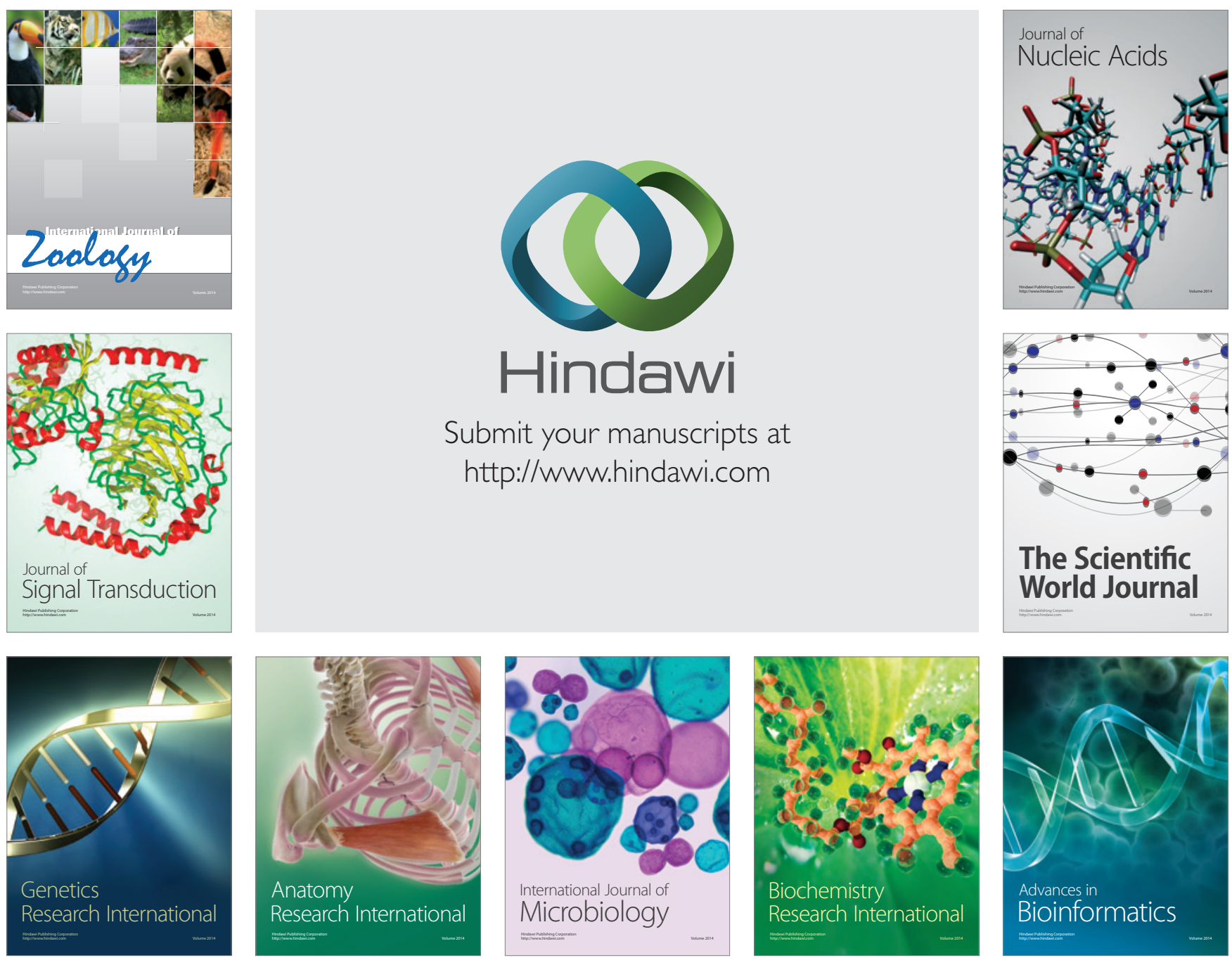

The Scientific World Journal
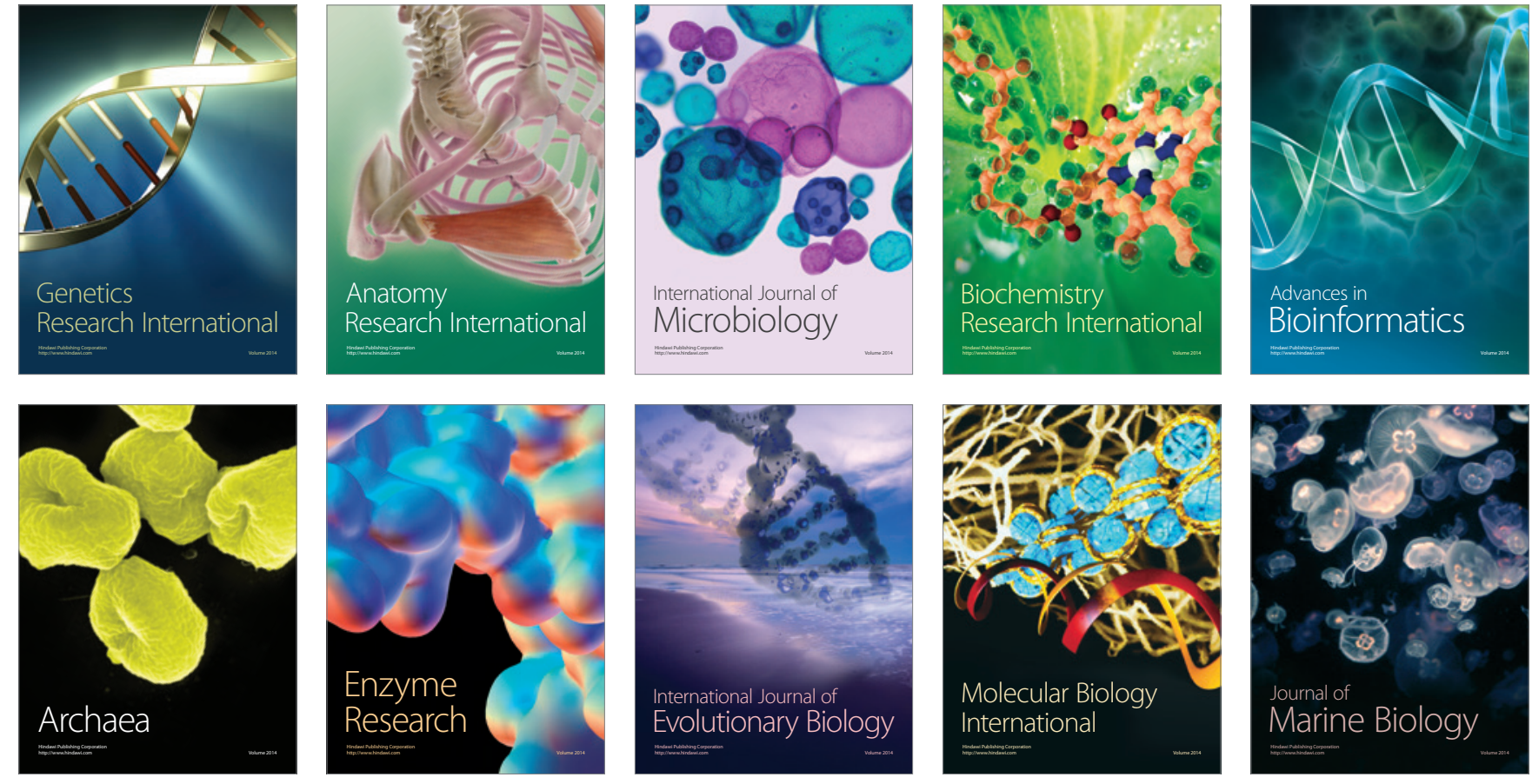